\title{
Cyclin E-CDK2 is a regulator of $\mathrm{p} 27^{\mathrm{Kip} 1}$
}

\author{
Robert J. Sheaff, ${ }^{1}$ Mark Groudine, ${ }^{1,4}$ Matthew Gordon, ${ }^{1}$ James M. Roberts, ${ }^{1,5}$ and \\ Bruce E. Clurman ${ }^{1-3,5}$ \\ Divisions of ${ }^{1}$ Basic Sciences and ${ }^{2}$ Clinical Research, Fred Hutchinson Cancer Research Center (FHCRC), Seattle, \\ Washington 98104; Departments of ${ }^{3}$ Medicine and ${ }^{4}$ Radiation Oncology, University of Washington, Seattle, Washington \\ 98104
}

\begin{abstract}
CDK inhibitors are thought to prevent cell proliferation by negatively regulating cyclin-CDK complexes. We propose that the opposite is also true, that cyclin-CDK complexes in mammmalian cells can promote cell cycle progression by directly down-regulating CDK inhibitors. We show that expression of cyclin E-CDK2 in murine fibroblasts causes phosphorylation of the CDK inhibitor p2 $7^{\mathrm{Kip} 1}$ on $\mathrm{T} 187$, and that cyclin E-CDK2 can directly phosphorylate p27 T187 in vitro. We further show that cyclin E-CDK2-dependent phosphorylation of p27 results in elimination of $\mathrm{p}_{27}$ from the cell, allowing cells to transit from $\mathrm{G}_{1}$ to $\mathrm{S}$ phase. Moreover, mutation of $\mathrm{T} 187$ in $\mathrm{p} 27$ to alanine creates a $\mathrm{p} 27$ protein that causes a $\mathrm{G}_{1}$ block resistant to cyclin $\mathrm{E}$ and whose level of expression is not modulated by cyclin $\mathrm{E}$. A kinetic analysis of the interaction between $\mathrm{p} 27$ and cyclin E-CDK2 explains how p27 can be regulated by the same enzyme it targets for inhibition. We show that p27 interacts with cyclin E-CDK2 in at least two distinct ways: one resulting in p27 phosphorylation and release, the other in tight binding and cyclin E-CDK2 inhibition. The binding of ATP to the CDK governs which state predominates. At low ATP $(<50 \mu \mathrm{M}) \mathrm{p} 27$ is primarily a CDK inhibitor, but at ATP concentrations approaching physiological levels $(>1 \mathrm{~mm}$ ) p27 is more likely to be a substrate. Thus, we have identified p27 as a biologically relevant cyclin E-CDK2 substrate, demonstrated the physiological consequences of p27 phosphorylation, and developed a kinetic model to explain how p27 can be both an inhibitor and a substrate of cyclin E-CDK2.
\end{abstract}

[Key Words: Cyclin; CDK; cell cycle; p2 $\left.7^{\mathrm{Kip} 1}\right]$

Received March 14, 1997; revised version accepted April 11, 1997.

Cyclin-dependent kinases (CDKs) become catalytically active or inactive in response to a variety of physiologic signals. CDK activation requires association with regulatory subunits called cyclins, as well as phosphorylation of CDK2 by the CDK-activating kinase (CAK) (Sherr 1994; Morgan 1995). Each phase of the cell cycle is characterized by the expression of a unique profile of cyclinCDK complexes. In mammalian cells, progression through $G_{1}$ is regulated by the activity of the D-type cyclins and cyclin $\mathrm{E}$, which associate with the CDK4/6 and CDK2 subunits respectively, whereas subsequent transitions through the cell cycle require cyclin A-CDK2, cyclin A-cdc2, and cyclin B-cdc2.

$\mathrm{CDK}$ inhibitors (CKIs) are negative regulatory proteins that bind to cyclin-CDK complexes and inhibit their catalytic activity (Sherr and Roberts 1995). CKIs are classified into two groups based on their protein sequence similarities and putative CDK targets. The INK4 proteins $(\mathrm{p} 15, \mathrm{p} 16, \mathrm{p} 18$, and $\mathrm{p} 19)$ specifically bind to and inhibit the cyclin D-associated kinases CDK4 and CDK6 (Serrano et al. 1993; Hirai et al. 1995; Quelle et al. 1995). Although the physiologic role of INK4 proteins remains

${ }^{5}$ Corresponding authors.

E-MAIL jroberts@fhcrc.org; bclurman@fhcrc.org; FAX (206) 667-5894. unclear, the pl6 gene is a tumor suppressor and has been implicated in a variety of human cancers (Kamb 1994; Nobori et al. 1994; Clurman et al. 1996a; Serrano et al. 1996). The results of in vitro experiments suggest that the second class of CKIs, the Cip/Kip proteins (p21, p27, and p57), are more promiscuous and potently inhibit the activity of most cyclin-CDK complexes, at least in vitro. Cip/Kip proteins appear to regulate cell proliferation by stopping cell cycle progression in response to a variety of anti-mitogenic signals. For example, p21 is transcriptionally induced by the p53 protein, and is a primary mediator of the p53-dependent $\mathrm{G}_{1}$ arrest that occurs following DNA damage (El-Diery et al. 1993; Gu et al. 1993; Harper et al. 1993; Xiong et al. 1993a,b; Dulic et al. 1994; Noda et al. 1994; Deng et al. 1995). In contrast, p27 appears to be primarily responsible for regulating CDK activity in response to extracellular antiproliferative cues (Polyak et al. 1994a; Slingerland et al. 1994; Toyoshima and Hunter 1994).

Any one of a number of antimitogenic conditions or agents--including mitogen starvation, cell-cell contact, loss of cell anchorage, damaged DNA, or transforming growth factor- $\beta$ (TGF- $\beta$ )-results in the formation of inactive cyclin E-CDK2 complexes and concomitant cell cycle arrest (Koff et al. 1993; Dulic et al. 1994; Firpo et al. 1994; Kato et al. 1994; Nourse et al. 1994; Polyak 
1994a,b; Coats et al. 1996; Fang et al 1996; Zhu et al. 1996). In every case, the inactivity of these complexes appears to be attributable to their association with a CKI. In all normal cells, p27 levels increase during entry into a quiescent or nondividing state, and rapidly decrease upon reentry into the cell cycle after stimulation with specific growth factors. Forced expression of p27 causes the cell cycle to stop in $G_{1}$ (Polyak et al. 1994b; Toyoshima and Hunter 1994), and, conversely, inhibition of $\mathrm{p} 27$ expression by antisense oligonucleotides results in the failure of mitogen-starved fibroblasts to exit the cell cycle on schedule (Coats et al. 1996). Mice with homozygous deletions of the p27 gene are larger than control mice as a result of increased numbers of cells in all tissues and organs, confirming the importance of $\mathrm{p} 27$ in the control of cell proliferation (Fero et al. 1996; Kiyokawa et al. 1996; Nakayama et al. 1996).

The abundance of the p27 protein is thought to be regulated by both translational and post-translational pathways, and less commonly at the level of transcription (Roberts et al. 1994; Pagano et al. 1995; Agrawal et al. 1996; Hengst and Reed 1996). The biochemical pathways through which $\mathrm{p} 27$ protein levels are linked to proliferative signals, however, have not been described. As detailed below, our analyses of the kinetic and molecular interactions between $\mathrm{p} 27$ and its putative target, cyclin E-CDK2, reveal that p27 can be both an inhibitor and a substrate of the cyclin E-CDK2 enzyme. We provide evidence that phosphorylation of $\mathrm{p} 27$ by cyclin E-CDK2 in vivo reverses the cell cycle block caused by p 27 and initiates a pathway leading to elimination of $\mathrm{p} 27$ from the cell. The conventional view has been that $\mathrm{CDK}$ inhibitors oppose the action of CDKs in order to enforce cell cycle arrest. Our data suggest that the reverse is also true, that CDKs inactivate CDK inhibitors to promote cell cycle progression.

\section{Results \\ Cyclin E-CDK2 catalytic activity is required to down-regulate $\mathrm{p} 27$ protein levels}

Forced expression of $\mathrm{p} 27^{\mathrm{Kip} 1}$ in proliferating cells arrests the cell cycle, presumably by inhibiting CDKs. It is thought that $\mathrm{p} 27$ prevents the execution of CDK-dependent cell cycle events by binding tightly to the enzyme and inhibiting its catalytic activity. A prediction of this model is that simultaneous overexpression of p27 with one of its cyclin or cyclin-CDK targets would titrate the $\mathrm{CDK}$ inhibitor and overcome the cell cycle arrest. Indeed, overexpression of cyclin $E$ prevents the $G_{1}$ arrest caused by p27 (Fig. 1A).

Surprisingly, however, when p27 was coexpressed with cyclin E-CDK2 it was eliminated from the cell (Fig. 1B). In contrast, p27 levels did not decline when cyclin E was coexpressed with an inactive CDK2 that cannot hydrolyze ATP (van den Heuval and Harlow 1993) (Fig. 1B). Therefore, the simple model that $\mathrm{p} 27$ was just sequestered into cyclin E-CDK2 complexes was insufficient to explain the interaction of cyclin E with $\mathrm{p} 27$ in cells, and
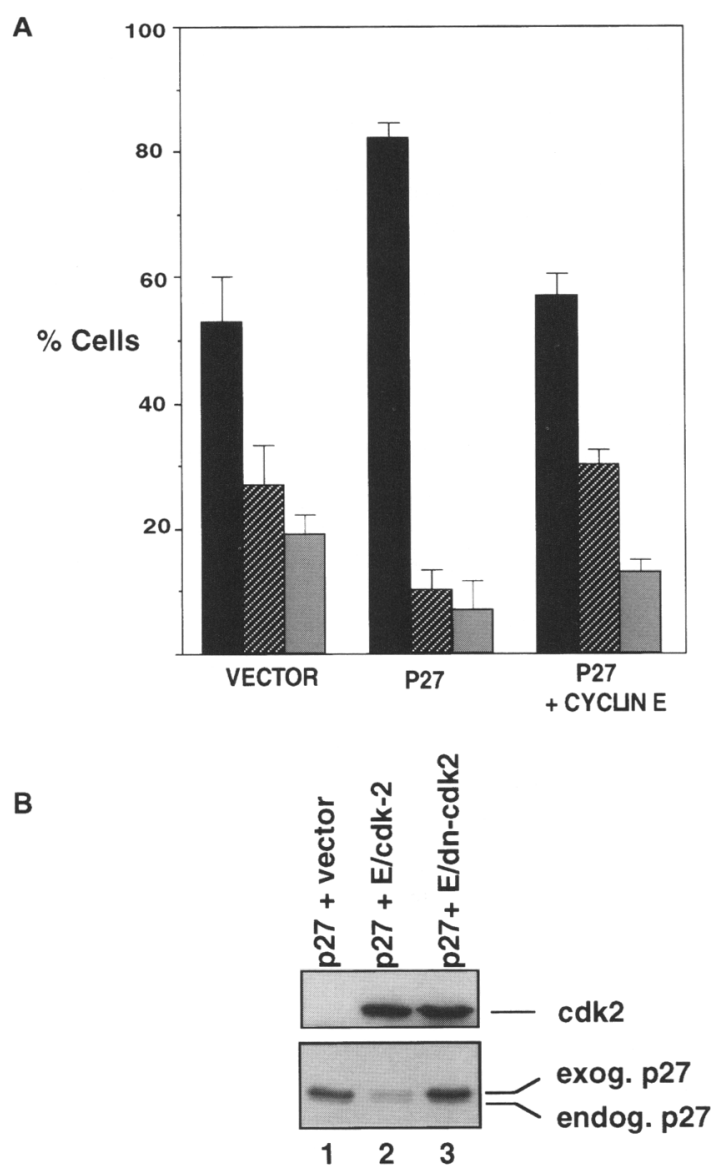

Figure 1. Cyclin E-CDK2 kinase activity overcomes a p27imposed $G_{1}$ arrest. $|A|$ Expression of p27 in NIH-3T3 cells causes a $G_{1}$ arrest that is overcome by cotransfection with cyclin E. Control cells were transfected with empty CS2MT vector alone. The figure shows the mean results obtained from three independent experiments with error bars depicting the standard deviations. (Solid bar) $\mathrm{G}_{1}$; (hatched bar) $\mathrm{S}_{\text {; }}$ (shaded bar) $\mathrm{G}_{2} \cdot(B)$ Coexpression of $\mathrm{p} 27$ in NIH-3T3 cells with catalytically active cyclin $\mathrm{E}-\mathrm{CDK} 2$ (lane 2 ) results in marked reduction of p27 expression. Cells were transfected with CS2p27 and either empty vector (lane 1), or vectors expressing cyclin $\mathrm{E}$ and wtCDK2 (lane 2) or cyclin E and dn-CDK2 (lane 3). The transfected p 27 protein is of human origin and migrates more slowly than the endogenous murine $\mathrm{p} 27$ protein.

the consequent reversal of the p27-imposed $G_{1}$ arrest. Based upon the observation that $\mathrm{p} 27$ is phosphorylated by cyclin E-CDK2 and that $\mathrm{p} 27$ is a phosphoprotein in vivo (see below), we considered the possibility that $\mathrm{p} 27$ phosphorylation by cyclin E-CDK2 might down-regulate p27 expression in the cell. In this model p27 is a substrate rather than an inhibitor of the cyclin E-CDK2 complex. This predicts that both cyclin E-CDK2 kinase activity and phosphorylation of p27 would be required for cyclin E to overcome a p27-imposed cell cycle block. We have confirmed each of these predictions.

This hypothesis was first tested by determining whether expression of a catalytically inactive cyclin 
E-CDK2 complex had any affect on either the p27-imposed $\mathrm{G}_{1}$ arrest or on $\mathrm{p} 27$ protein expression. Mutation of specific residues within the conserved cyclin box created a cyclin E mutant, cyclin E(188-192A), that bound to CDK2, but did not make an active kinase (Fig. 2A). Although the reasons for this have not been determined, the crystal structure of cyclin A-CDK2 suggests that residues mutated in cyclin $\mathrm{E}(188-192 \mathrm{~A})$ are probably located in close proximity to T160 in the T loop of CDK2, the site of CDK2 phosphorylation by CAK (Russo et al. 1996). Therefore, it is possible that T160 may not be phosphorylated efficiently in the cyclin E(188-192A)CDK2 complex, or that the phosphorylated $\mathrm{T}$ loop is prevented from moving away from the catalytic cleft of the enzyme. Regardless, overexpression of cyclin E/188192A) did not accelerate cells through $G_{1}$, consistent with its inability to fully activate CDK2. We found that cyclin $E(188-192 A)$ did not overcome the $G_{1}$ block caused by p27 (Fig. 2B), consistent with our observation that p27 levels were unaffected (data not shown).

The failure of the inactive CDK2 or cyclin $\mathrm{E} / 188_{-}$ 192A) to eliminate p27 did not result from their inability to form cyclin-CDK-p27 complexes. Both wild-type cyclin $\mathrm{E}$ and cyclin $\mathrm{E}(188-192 \mathrm{~A})$ bound similar amounts of CDK2 (Fig. 2C). Furthermore, inactive cyclin E complexes [cyclin E-dn-CDK2 and cyclin E(188-192A)CDK2] bound to at least as much, if not more p27 than catalytically active cyclin E-CDK2 complexes (Fig. 2C).
We therefore examined the possibility that phosphorylation of $\mathrm{p} 27$ by cyclin E-CDK2 was required for $\mathrm{p} 27$ elimination.

\section{Cyclin E-CDK2 phosphorylates p27 on T187}

Inspection of the $\mathrm{p} 27$ amino acid sequence revealed a CDK phosphorylation consensus site TPKK at position 187 in the carboxyl terminus. Wild-type p27 was phosphorylated by cyclin E-CDK2 in vitro(Fig. 3A), but when threonine 187 was changed to alanine, phosphorylation of the mutant protein ( $227 \mathrm{~T} 187 \mathrm{~A})$ decreased by at least 10-fold. Mutation of the CDK-consensus phosphorylation site from TPKK to TPAA also decreased phosphorylation to a similar extent (not shown). These experiments identified T187 as the major cyclin ECDK2 phosphorylation site on p27, at least in vitro. Two-dimensional phosphopeptide mapping of p27 revealed a single major CDK phosphorylated peptide (A), and one minor phosphopeptide (B) (Fig. 3B). As predicted, phosphoamino acid analysis showed largely phosphothreonine, and considerably smaller amounts of phosphoserine (Fig. 3C). Mutation of T187 did not obviously affect the inhibitory activity of $\mathrm{p} 27$, because a comparison of $\mathrm{p} 27(\mathrm{~T} 187 \mathrm{~A})$ with wild-type $\mathrm{p} 27$ revealed similar potency against cyclin E-CDK2 phosphorylation of histone $\mathrm{H} 1$ in vitro (data not shown).

To determine whether $\mathrm{p} 27$ is phosphorylated on T187
A

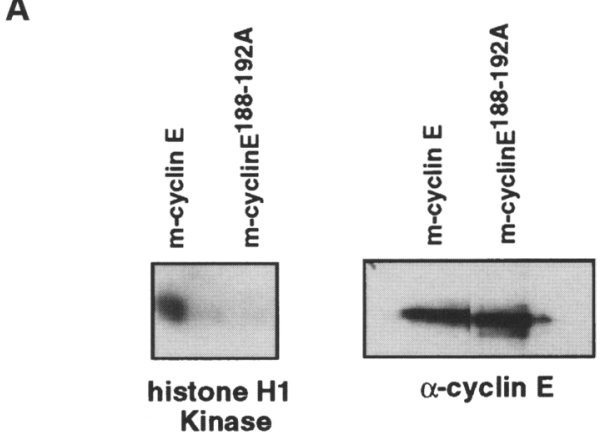

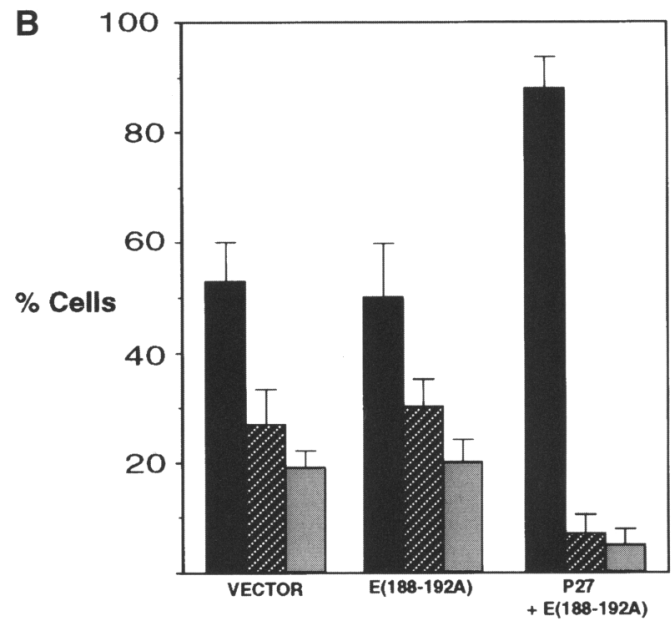

Figure 2. Inactive cyclin $\mathrm{E}-\mathrm{CDK} 2$ complexes fail to overcome a p27-imposed $\mathrm{G}_{1}$ arrest. (A) Cyclin E(188-192A)CDK2 complexes are catalytically inactive. (Left) The histone $\mathrm{Hl}$ kinase activity in anti-myc tag immunoprecipitates from cells transfected with vectors expressing either myc epitope-tagged wild-type cyclin E or cyclin E/T188192A). (Right) The expression of the exogenous cyclin $\mathrm{E}$ proteins. $(B)$ Expression of cyclin E(T188-192A) does not
wo independent experiments. Bars as in Fig. 1. (C) Cyclin overcome a 27 -induced $\mathrm{G}_{1}$ arrest. The results depict the means from two independent experiments. Bars as in Fig. 1. $(C) \mathrm{Cyclin}$ $\mathrm{E}(\mathrm{T} 188-192 \mathrm{~A}$ ) binds both CDK2 and $\mathrm{p} 27$. Cells were cotransfected with vectors expressing either cyclin E (lanes 1-4) or cyclin precipitated with $9 \mathrm{E} 10$ antibody (anti-myc tag) and the associated $\mathrm{p} 27$ and CDK2 visualized by immunoblotting. 
A

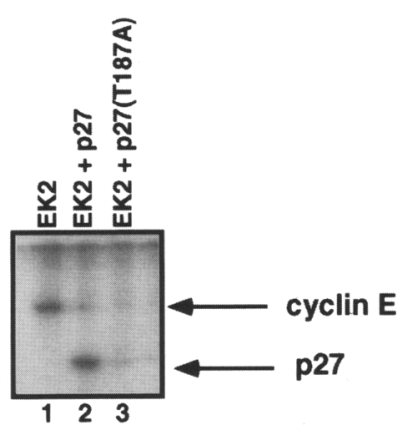

B

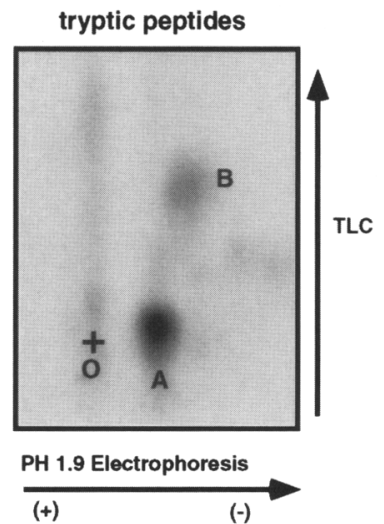

C

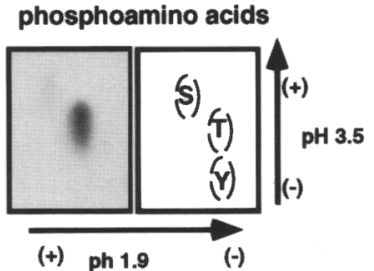

Figure 3. P27 is phosphorylated on thr 187 by purified cyclin E-CDK2. (A) Purified, bacterially expressed p27 or p27(T187A) $\{1 \mu \mathrm{M}$, lanes 2,3) was added to active cyclin E-CDK2 complexes purified from insect cells infected with recombinant baculoviruses (see Materials and Methods $)$ in the presence of $\left[\gamma-{ }^{2} \mathrm{P}\right]$ ATP. No p 27 protein was included in lane 1 . $(B)$ Tryptic phosphopeptide analysis of in vitro phosphorylated $\mathrm{p} 27$ protein eluted from a denaturing polyacrylamide gel. The position of the origin $(\mathrm{O})$ is noted. A single major phosphopeptide (A) and minor phosphopeptide (B) are seen. $(C)$ Phosphoamino acid analysis of the p27 protein analyzed in $B$ demonstrates that the vast majority of the cyclin E-CDK2-dependent 27 phosphorylation is on threonine.

in vivo we analyzed the phosphorylation state of $\mathrm{p} 27$ in NIH-3T3 cells (Fig. 4). We were unable to study the phosphorylation state of the endogenous cellular $\mathrm{p} 27$ protein, perhaps because it is unstable once it is phosphorylated. Instead, p27 was transfected into cells together with a tetracycline-repressible vector encoding cyclin $\mathrm{E}$.
A

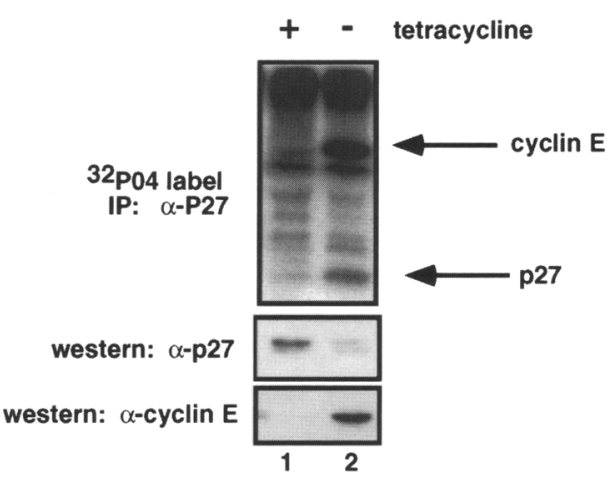

B

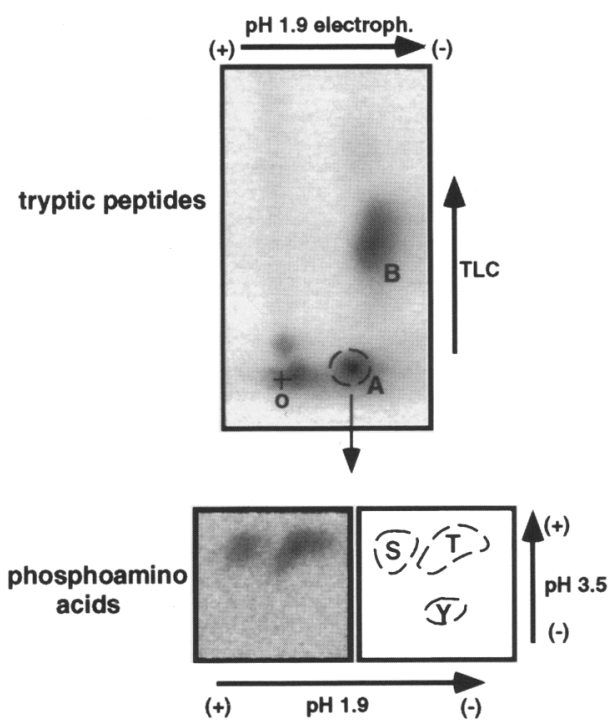

p27 (T187A)

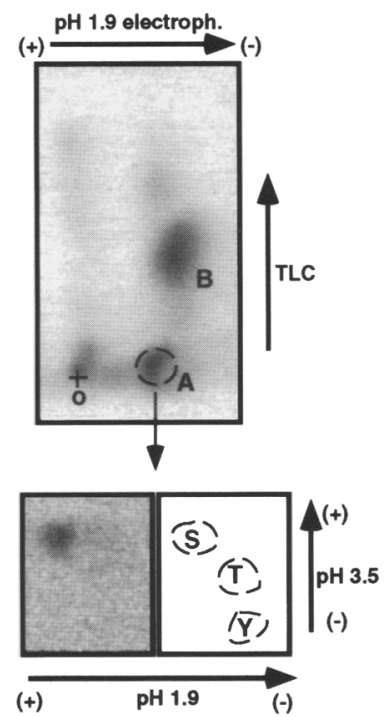

Figure 4. p27 is phosphorylated on T187 in vivo. $(A)$ Induction of cyclin E expression leads to increased p27 phosphorylation in vivo. $\mathrm{NIH}-3 \mathrm{~T} 3$ cells were transiently transfected with vectors expressing $\mathrm{p} 27, \mathrm{CDK} 2$, and tetracycline-regulatable cyclin $\mathrm{E}$ and labeled with $\left.{ }^{32} \mathrm{P}\right]$ orthophosphate (see Results and Materials and Methods for details). The removal of tetracycline (lane 2) led to high levels of cyclin E expression, decreased p27 expression, and increased p27 phosphorylation compared with cells grown continually in the presence of tetracycline (lane 1). The positions of phosphorylated p27 and cyclin E are indicated. $(B)$ Tryptic phosphopeptide and phosphoamino acid (PAA) analysis of in vivo phosphorylated p27 and p27(T187A). (Left) In vivo phosphorylated p27 protein eluted from a denaturing acrylamide gel as in $A$ is composed of two major phosphopeptides labeled $\mathrm{A}$ and $\mathrm{B}$. Phosphopeptide A corresponds to the major in vitro cyclin E-dependent phosphopeptide shown in Fig. 3. Phosphopeptide A that was recovered from the TLC plate contained both phosphothreonine and phosphoserine, indicating the presence of two distinct in vivo phosphorylation sites within this tryptic peptide. (Right) A parallel analysis of in vivo-phosphorylated p27(T187A) demonstrates that although the tryptic phosphopeptide map is similar to that generated from wild-type $\mathrm{p} 27$, phosphopeptide A derived from $\mathrm{p} 27(\mathrm{~T} 187 \mathrm{~A})$ contains only phosphoserine. 
Twenty-four hours post-transfection p27 had accumulated to high levels, at which time tetracycline was removed from the medium to induce cyclin $\mathrm{E}$ expression. Cells were then labeled with $\left[{ }^{32} \mathrm{P}\right]$ orthophosphate, and p27 phosphorylation analyzed by SDS-PAGE of anti-p27 immunoprecipitates. This protocol was designed to cause a synchronous burst of $\mathrm{p} 27$ phosphorylation, after which the cells could be harvested prior to the complete elimination of the phosphorylated p 27 protein. Control cells were cultured in the continued presence of tetracycline. In the absence of cyclin E expression (Fig. 4A, lane 1) p27 levels were high, yet only very low levels of phosphorylated $\mathrm{p} 27$ were detected. Induction of cyclin $\mathrm{E}$ (Fig. $4 \mathrm{~A}$, lane 2) correlated with a large increase in p27 phosphorylation, even though there was a concomitant decline in total p27 protein levels (Fig. 4A). Therefore, the stoichiometry of $\mathrm{p} 27$ phosphorylation was considerably greater in the presence of cyclin $\mathrm{E}$.

Induction of cyclin $E$ resulted in two major $\mathrm{p} 27$ phosphopeptides, A and B (Fig. 4B). Phosphopeptide A corresponded to the major phosphopeptide observed after in vitro phosphorylation of $\mathrm{p} 27$ by cyclin E-CDK2. Phosphoamino acid analysis showed that peptide A contained both phosphothreonine and phosphoserine, whereas a parallel analysis of $\mathrm{p} 27(\mathrm{~T} 187 \mathrm{~A})$ revealed only phosphoserine. This directly showed that $\mathrm{p} 27$ is phosphorylated on $\mathrm{T} 187$ in vivo.

In vivo-labeled p27 showed an altered ratio of phosphopeptides A and B when compared with in vitro-la- beled $\mathrm{p} 27$. The relative deficiency of phosphopeptide $\mathrm{A}$ is possibly explained by the relative instability of $\mathrm{p} 27$ phosphorylated at this site in vivo. This would also account for the relative decrease in phosphothreonine versus phosphoserine in vivo. Alternatively, there may be other kinases that also phosphorylate $\mathrm{p} 27$ in vivo in a cyclin E-dependent manner.

The above experiments show that increased expression of cyclin E correlates with p27 phosphorylation in vivo, but do not rule out the possibility that phosphorylation requires an intermediary kinase. To determine whether cyclin E-CDK2 phosphorylates $\mathrm{p} 27$ directly, we examined p27-cyclin E-CDK2 complexes immuneprecipitated from cells (Fig. 5). NIH-3T3 cells were cotransfected with cyclin E, p27, and CDK2 (or mutant forms of these proteins), and cyclin $\mathrm{E}$ with its associated proteins was harvested by immunoprecipitation from cell extracts with anti-cyclin $\mathrm{E}$ antiserum. Immunoblotting confirmed the presence of p27 in the cyclin E immunoprecipitates (Fig. 5A). Incubation of these complexes with $\left[\gamma^{32} \mathrm{P}\right] \mathrm{ATP}$ in vitro resulted in phosphorylation of p27 (Fig. 5A) predominantly on threonine within peptide A (Fig. 5B,C). Very little phosphorylation of p27 was observed if the cyclin $\mathrm{E}$ complexes contained a catalytically inactive CDK2 (Fig. 5A), demonstrating that phosphorylation required active $\mathrm{CDK} 2$ and was not attributable to another associated protein kinase. Phosphorylation was also eliminated if the complexes contained p27(T187A) instead of wild-type $\mathrm{p} 27$, confirming that this is a major
Figure 5. Immunoprecipitates of cyclin E-CDK2-p27 complexes assembled in vivo phosphorylate p27 on T187A. (A) Lysates from NIH-3T3 cell transfected with vectors expressing myc epitope-tagged cyclin $\mathrm{E}$ and either catalytically active (lane 1,2) or inactive (lanes 3,4) CDK2 and either p27 (lanes 1,4) or p27(T187A) (lane 2) were immunoprecipitated with anti-myc tag antibody. Catalytically active cyclin E-CDK2 efficiently phosphorylated wild-type $\mathrm{p} 27$, but not $\mathrm{p} 27(\mathrm{~T} 187 \mathrm{~A})$, despite equal amounts of cyclin E-associated $\mathrm{p} 27$ protein in the immunoprecipitates. p27 was not phosphorylated by catalytically inactive cyclin E-dn-CDK2 complexes (lane 4). (B) Tryptic phosphopeptide and (C) phosphoamino acid analyses demonstrate that p27 in these complexes is phosphorylated by cyclin E-CDK2 predominantly on phosphopeptide $\mathrm{A}$, and that phosphopeptide A contains only phosphothreonine.
A

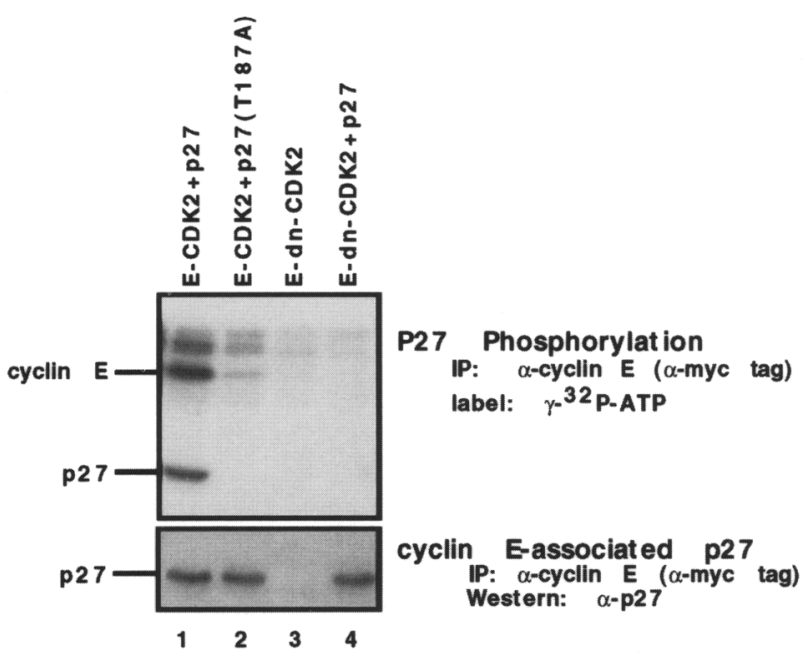

B tryptic peptides

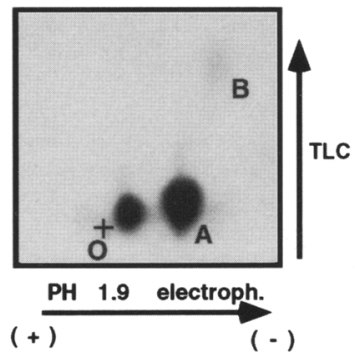

C phosphoamino acids

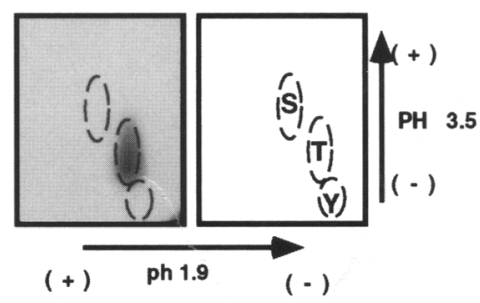


site of p27 phosphorylation within cyclin E-CDK2-p27 complexes that had assembled in vivo.

\section{Mutation of its CDK phosphorylation site stabilizes p27 and results in an irreversible $G_{1}$ arrest}

We found that expression of the p27 mutant p27(T187A), which has a threonine to alanine change at the major CDK phosphorylation site, imposed a $G_{1}$ block that could not be reversed by cyclin $\mathrm{E}$ (Fig. 6A). Therefore, both cyclin E-CDK2 kinase activity and this CDK2 phosphorylation site on $\mathrm{p} 27$ are required for cell cycle progression in this assay. Furthermore, whereas cyclin E-CDK2 drastically reduced the levels of wild-type p27, it had only a minimal effect on p27(T187A) (Fig. 6B). The simplest interpretation of these data is that direct phosphorylation of p27 by cyclin E-CDK2 down-regulates p27. The ability of cyclin E-CDK2 to overcome the $G_{1}$

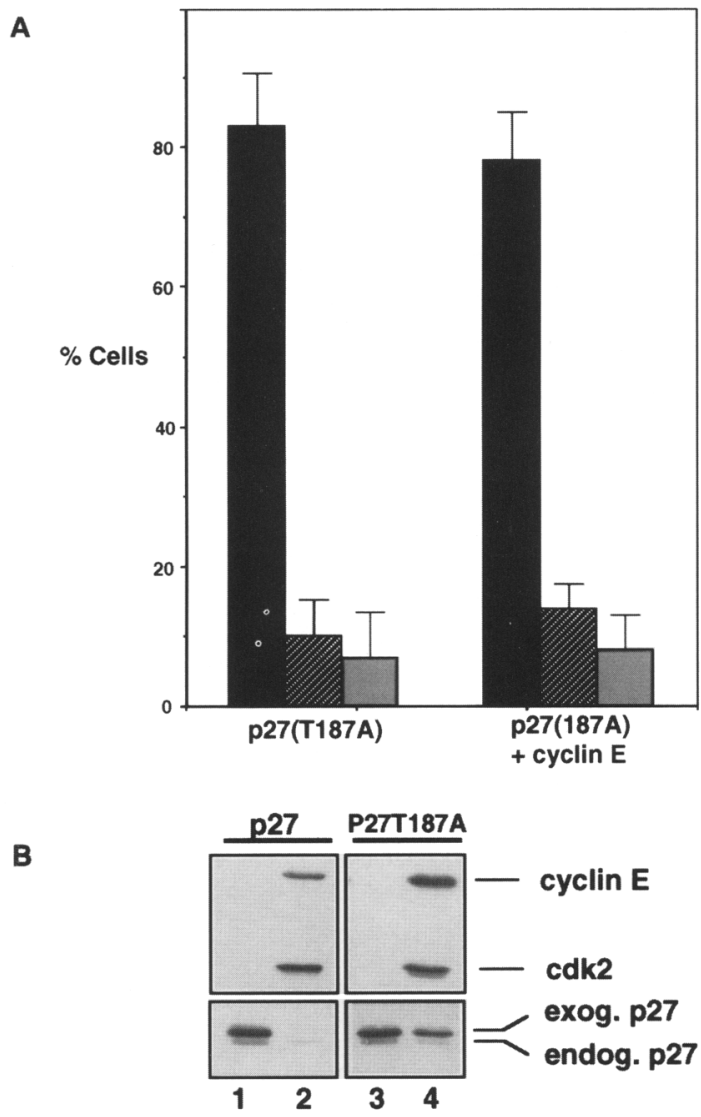

Figure 6. $(A) \mathrm{A}$ cell cycle arrest imposed by $\mathrm{p} 27(\mathrm{~T} 187 \mathrm{~A})$ is not overcome by cyclin E-CDK2. The mean results from three in dependent experiments are shown with the standard deviations. The vector-only controls for these three experiments are shown in Fig. 1A. Bars as in Fig. 1. (B) Expression of p27(T187A) is resistant to cyclin E-CDK2 activity. Lysates from cells cotransfected with either p27 (lanes 1,2) or p27/T187A) |lanes 3.4) and vector (lanes 1,3) or cyclin E-CDK2 (lanes 2,4). Immunoblots were probed with antibodies to $\mathrm{p} 27, \mathrm{CDK} 2$, and cyclin $\mathrm{E}$ (antimyc tagl, and the position of these proteins is indicated. arrest imposed by $\mathrm{p} 27$ paralleled its ability to eliminate p27 from the cell. Both required that $\mathrm{p} 27$ be a substrate, not an inhibitor of cyclin E-CDK2.

\section{Cyclin D1-CDK4 neither phosphorylates $p 27$ nor modulates its abundance}

To determine whether phosphorylation of T187 in p27 is a specific property of cyclin $E$ we compared cyclin E-CDK2 and cyclin D-CDK4, the two CDKs active during $G_{1}$ when 27 protein levels normally decline. Cyclin Dl and CDK4 were cotransfected into NIH-3T3 cells together with $\mathrm{p} 27$. Like cyclin $\mathrm{E}$, cyclin D1 was able to override the p27-imposed $\mathrm{G}_{1}$ block and promote entry into $S$ phase (Fig. 7A). But in contrast to what happens with cyclin E, cyclin Dl-dependent S-phase entry was not accompanied by a decline in 27 protein levels |Fig. 7B). Unlike p27-cyclin E complexes, the p27 bound to cyclin D1 was not phosphorylated (Fig. 7C). Nor did recombinant cyclin D1-CDK4 phosphorylate p27 in vitro (not shown). These data showed that cyclin D1-CDK4 phosphorylates p27 much less effectively than does cyclin E-CDK2, and does not modulate p27 protein levels in the cell. The data further show that $\mathrm{S}$ phase, per se, is not sufficient to induce the elimination of $p 27$ because cyclin Dl-transfected cells entered S phase without any change in $\mathrm{p} 27$ protein levels.

\section{Kinetic analysis of the interaction of p27 with cyclin E-CDK2}

Our data suggested that cyclin E-CDK2 regulates p27 in the cell. One difficulty with this idea is that previous data, including the crystal structure of the p27-cyclin A-CDK2 complex, have been interpreted to suggest that p27 is simply a tight binding inhibitor of cyclin-CDK catalytic activity. How can an inhibitor be effectively regulated by the very molecule it targets for inhibition? An answer to this question cannot be derived from the crystal structure of the p27-cyclin-CDK complex nor from molecular binding studies (Lou et al. 1995). Both of these approaches offer detailed information about the single thermodynamically most favorable interaction under specific reaction conditions, but do not describe the pathways leading to those states. Moreover, the carboxyl terminus of $\mathrm{p} 27$ is missing from the crystal structure so that the relationship between the CDK2 phosphorylation site and the CDK2 active site remains unknown. Accordingly, we turned to a kinetic analysis of the interaction between $\mathrm{p} 27$ and cyclin E-CDK2.

To determine whether phosphorylation of $\mathrm{p} 27$ represented stoichiometric phosphorylation of a single tightly bound p 27 molecule by each cyclin-CDK complex, we examined the kinetics of this reaction. The time course of p27 phosphorylation in the absence of any other substrate showed a burst of $\mathrm{p} 27$ phosphorylation followed by conversion to a slower rate (Fig. 8A). This might represent the rapid binding and phosphorylation of $\mathrm{p} 27$, followed by slow release of the product: a classic single turnover reaction. If this were the case, then preincubat- 
A

\begin{tabular}{|c|c|c|}
\hline Transfected Plasmids & \% G1 & \%S + G2 \\
\hline empty vector & 56.2 & 43.8 \\
\hline p27 & 79.1 & 20.9 \\
\hline cyclin E-CDK2 & 23.5 & 76.5 \\
\hline p27+ cyclin E-CDK2 & 23.3 & 76.7 \\
\hline cyclin D-CDK4 & 32.3 & 67.7 \\
\hline p27 +cyclin D-CDK4 & 30.7 & 69.3 \\
\hline
\end{tabular}
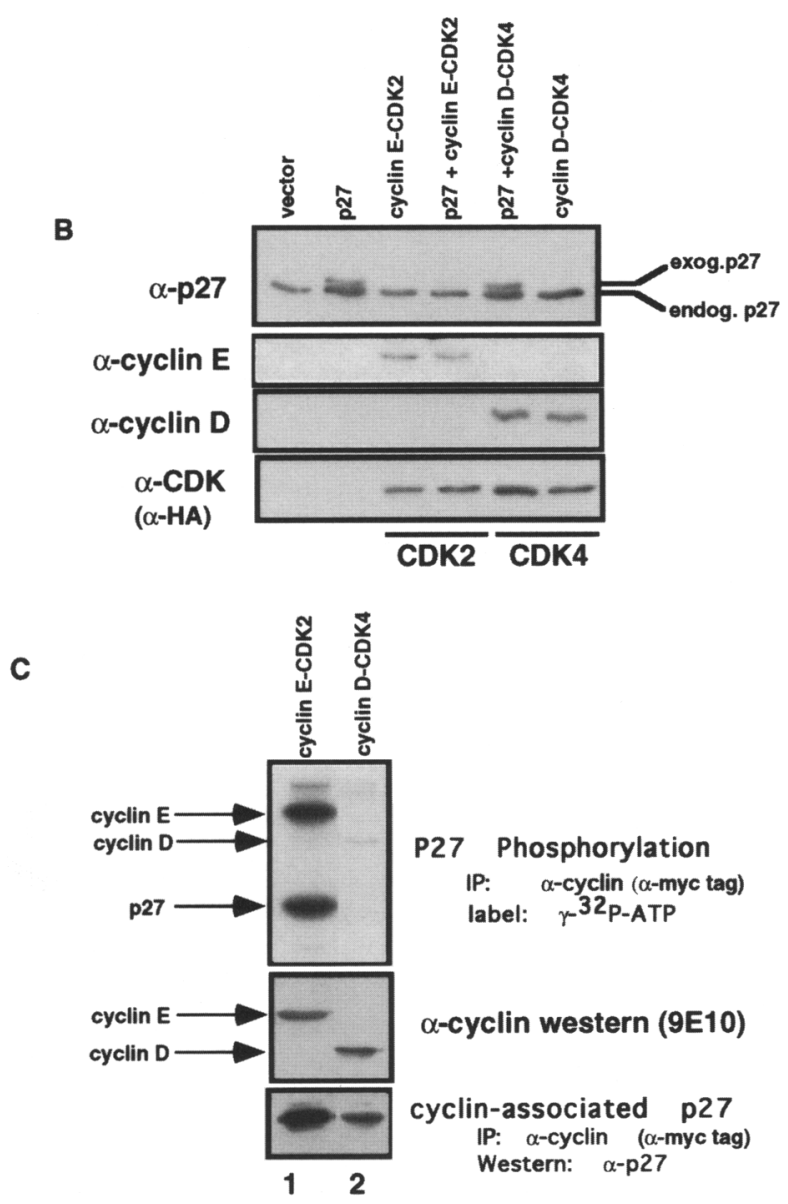

Figure 7. Cyclin D-CDK4 neither phosphorylates nor eliminates 27 in vivo. $(A)$ Cell cycle kinetics of NIH-3T3 cells transfected with the indicated expression vectors. $(B)$ Coexpression of cyclin D-CDK4 does not lead to elimination of p27. Western analysis of exogenous $\mathrm{p} 27$, cyclin, and CDK proteins from $\mathrm{NIH}$ 3T3 cells transfected with the indicated plasmids. Both the CDK2 and CDK4 proteins were HA epitope-tagged and visualized with anti-HA antibody (12CA5) (C) P27 is not phosphorylated by in vivo assembled complexes containing cyclin D-CDK4. Lysates from NIH-3T3 cell transfected with vectors expressing p27 and either myc epitope-tagged cyclin E and CDK2 (lane 1) or myc epitope-tagged cyclin D1 and CDK4 (lane 2) were immunoprecipitated with anti-cyclin antibody (antimyc tag) followed by the addition of $\left[\gamma_{-}{ }^{32} \mathrm{P}\right] \mathrm{ATP}$ to the washed immunoprecipitates.

ing p27 and cyclin E-CDK2 should have no effect on the burst size, because upon the addition of ATP, p27 should still be rapidly phosphorylated and released slowly. Surprisingly, however, when we preincubated p27 and cyclin E-CDK2 and then added ATP, the burst was lost and only the slow rate of $\mathrm{p} 27$ phosphorylation remained (Fig. 8A). The same results were obtained when cyclin E-CDK2 and $\mathrm{p} 27$ were preincubated in the presence of EDTA to ensure that p27 was not being phosphorylated during the preincubation (data not shown). Preincubating of enzyme in the absence of p27 does not result in the loss of catalytic activity (data not shown). Thus, preincubation of p27 and cyclin E-CDK2 results in a form of the complex that is incapable of rapidly phosphorylating p27.

This experiment suggests that p27 binds to cyclin E-CDK2 in at least two ways: first as a substrate (i.e., loose binding), and then as an inhibitor (i.e., tight binding). We reasoned that the initial interaction of $\mathrm{p} 27$ with cyclin E-CDK2 is an enzyme-substrate interaction that favors p 27 phosphorylation and gives the burst. Over time, however, an equilibrium is achieved between tight and loose binding of p27 to cyclin E-CDK2. Thus the burst does not necessarily represent a single turnover, but rather the amount of 27 phosphorylated in the time required to convert to the inhibited form of the complex. The termination of the burst represents inhibition of catalytic activity by $\mathrm{p} 27$, and the final slow rate of $\mathrm{p} 27$ phosphorylation is a measure of the equilibrium distribution between the catalytically active and inactive forms of the enzyme. Hence, under these conditions cyclin E-CDK2 is largely inactive at equilibrium, probably by its tight association with $\mathrm{p} 27$ (see below).

\section{Increasing ATP competes with inactivation of cyclin $E-C D K 2$}

A prediction of these ideas is that conditions that favor the enzyme-substrate interaction might compete with the interaction resulting in inhibition of catalytic activity (i.e., shift the equilibrium toward the active form of the enzyme). This hypothesis was confirmed when we examined the effect of ATP concentration on the rate of p27 phosphorylation. Increasing the ATP concentration (in the absence of preincubation) increased both the size of the burst and the slow rate (Fig. 8B). Again, if the burst represented a single turnover reaction with product release as the rate determining step, increasing the ATP should have had no effect on the burst size. Repeating the experiment with higher ATP concentrations (up to 1 $\mathrm{mm}$ ) showed that the slow rate continued to approach the rate of the burst (data not shown). The fact that increasing ATP increases the slow rate suggests that ATP competes with enzyme inactivation. Therefore, under more physiologic ATP concentrations cyclin E-CDK2 remains largely active at equilibrium despite the presence of $\mathrm{p} 27$.

These results suggest that the initial interaction of $\mathrm{p} 27$ with the cyclin E-CDK2 complex is transitory, with $\mathrm{p} 27$ more likely to be phosphorylated and released rather than binding tightly. We confirmed this prediction by determining that at high ATP concentrations the amount of phosphorylated p27 was 10-25 times greater than the amount of cyclin E-CDK2 in the reaction (see Materials and Methods). Thus, physiological ATP con- 


\section{No pre-incubation p27 pre-incubation}

A
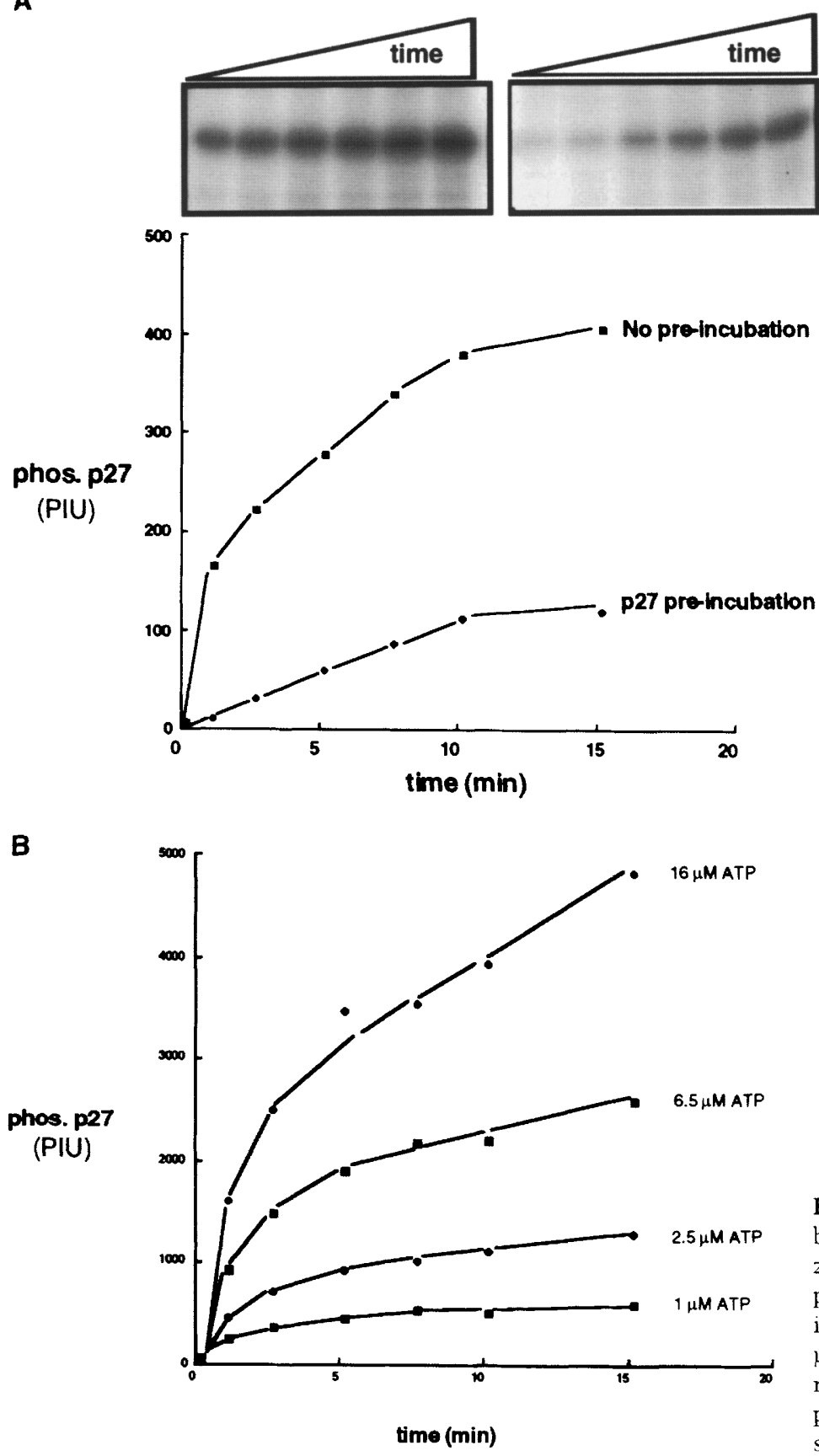

Figure 8. $|A|$ Time courses of $\mathrm{p} 27(1 \mu \mathrm{M})$ phosphorylation by cyclin E-CDK2 when the reaction is initiated with enzyme (no preincubation) or when enzyme and p27 are first preincubated for $10 \mathrm{~min} .(B)$ Increasing ATP competes with inactivation of cyclin E-CDK2. Phosphorylation of p27 (1 $\mu \mathrm{M}$ ) over time as a function of ATP concentration. The reaction was initiated with enzyme. The amount of phosphorylated p27 was determined by PhosphorImager analysis and corrected for the changing specific activity.

centrations (1-4 mM; Hauschka 1973) favor p27 phosphorylation and release rather than tight binding and inhibition.

\section{Assembly of the cyclin E-p27 complex}

We can infer from the kinetics that progression of $\mathrm{p} 27$ to a tightly bound state is slow. To test this directly, we measured the pre-steady-state rate of cyclin E-CDK2p27 complex assembly using a trapping assay (Fig. 9). p27 and cyclin $\mathrm{E}-\mathrm{CDK} 2$ were preincubated for short periods of time and then diluted into a trap solution containing an excess of $\mathrm{p} 21^{\mathrm{Cip} 1}$. $\mathrm{p} 21^{\mathrm{Cip} 1}$ is a CKI that also tightly binds the cyclin E-CDK2 complex. The p21 trap serves two purposes. 1) Upon dilution into the trap any free cyclin E-CDK2 will be bound by excess p21, effectively removing it from the reaction. 2) If $\mathrm{p} 27$ dissociates from cyclin E-CDK2 while in the presence of the trap, its rebinding is prevented. Thus this technique examines the time-dependence of the cyclin E-CDK2-p27 com- 
A On Rate Trapping Assay

Figure 9. Determination of p27-cyclin E-CDK2 assembly and disassembly rates. Shown are schematic diagrams describing the trapping assay for determining association and dissociation rates. $(A)$ The presteady-state association of $\mathrm{p} 27$ with cyclin E-CDK2 as a function of time. $(B)$ The rate of $\mathrm{p} 27$ dissociation at equilibrium. In the background lane $(\mathrm{Bg})$, enzyme was diluted into p27 plus the p21 trap, whereas in the control lane $(C)$ the p21 trap was absent (see Results for details).
B Off Rate Trapping Assay

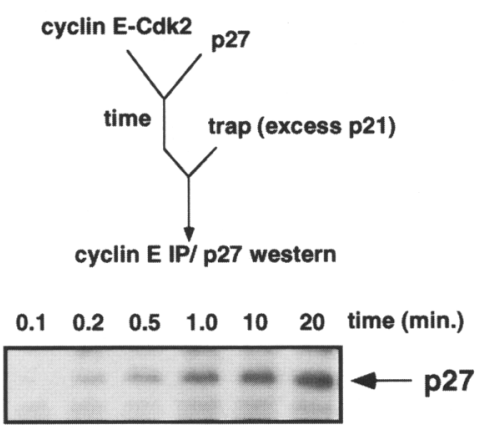

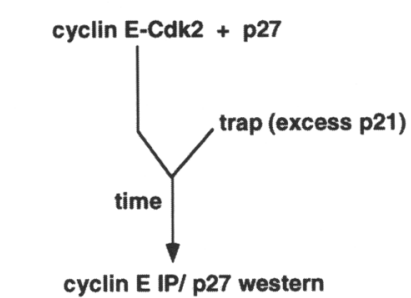

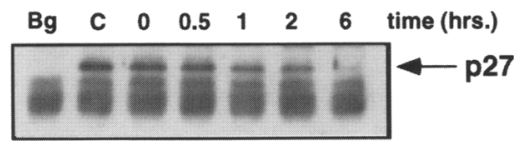

plex assembly rather than simply determining the amount of $\mathrm{p} 27$ bound at equilibrium. To ensure the concentration of $\mathrm{p} 21$ in the trap was in sufficient excess, cyclin E-CDK2 was added to a mixture containing p21 and p27. No p27 associated with cyclin E-CDK2, indicating that the amount of $\mathrm{p} 21$ in the trap prevented $\mathrm{p} 27$ from binding (Fig. 9B, lane Bg).

If p27 binds the enzyme complex rapidly and tightly during the preincubation [close to the diffusion controlled rate $10^{6}-10^{8} \mathrm{M} / \mathrm{sec}$ (Fersht 1984)], then there should be no change in the amount of p27 associated with cyclin E-CDK2 over the time course measured. Alternatively, if p 27 binds the enzyme complex slowly, or progression to a tightly bound form is slow, then the amount of p27 associated with cyclin E-CDK2 should increase over time. Figure $9 \mathrm{~A}$ shows that as the preincubation time increases, the amount of p27 tightly associated with the enzyme also increases. This clearly shows that p27 does not rapidly and tightly bind to cyclin E-CDK2. Furthermore, the time required for stable association is consistent with the burst kinetics of $\mathrm{p} 27$ phosphorylation. Thus, p27 interacts rapidly but transiently in a form that results in 27 phosphorylation, rather than simply binding cyclin E-CDK2 slowly.

The kinetics of $\mathrm{p} 27$ phosphorylation at low ATP concentrations also imply that at equilibrium p27 resides in a tightly bound state that inhibits kinase activity. We therefore measured the stability of the cyclin E-CDK2p27 complex at equilibrium (Fig. 9B). Purified cyclin $\mathrm{E}-\mathrm{CDK} 2$ and $\mathrm{p} 27$ were preincubated for $10 \mathrm{~min}$ at $37^{\circ} \mathrm{C}$, then diluted into a trap solution containing excess $\mathrm{p} 2 \mathrm{l}$. Again, the p21 trap ensures that once p27 dissociates from cyclin $\mathrm{E}-\mathrm{CDK} 2$ rebinding cannot occur. At the indicated times, aliquots were withdrawn and the amount of p27 still associated with the enzyme determined. Approximately half the $\mathrm{p} 27$ dissociated in $2 \mathrm{hr}$, indicating that p27 is tightly associated with cyclin E-CDK2 at equilibrium.

The trapping data suggest that assembly of a catalytically inactive p27-cyclin E-CDK2 complex proceeds by the slow conversion of a loosely bound, transient intermediate to a tightly bound form. This description of the p27-cyclin E-CDK2 reaction pathway is therefore in agreement with the kinetics of p27 phosphorylation. Phosphorylation of $\mathrm{p} 27$ occurs before conversion to the tightly bound state, that is, in a loosely bound intermediate, and ATP competes with inhibition by preventing conversion to the tightly bound cyclin E-CDK2-p27 complex.

\section{Inhibition of histone $\mathrm{H} 1$ phosphorylation by $\mathrm{p} 27$}

The kinetic description of the p27 interaction with cyclin E-CDK2 is entirely consistent with its ability to potently inhibit histone $\mathrm{Hl}$ phosphorylation. Purified cyclin E-CDK2 efficiently catalyzes the transfer of $\left.{ }^{32} \mathrm{P}\right]$ phosphate from ATP to histone $\mathrm{H} 1$. The addition of increasing concentrations of purified $\mathrm{p} 27$ to the reaction inhibits phosphorylation of histone $\mathrm{H} 1$ (Fig. 10A). When we examined the time course of inhibition, however, initiating the reaction with enzyme results in a burst of histone $\mathrm{H} 1$ phosphorylation followed by conversion to a slower rate (Fig. 10B). In contrast, preincubating enzyme with $\mathrm{p} 27$ for $10 \mathrm{~min}$ prior to adding histone $\mathrm{H} 1$ alleviates this time dependence and results in the maximal amount of inhibition at all time points. Note that the shape of this curve is similar to both the rate of $\mathrm{p} 27-$ cyclin E-CDK2 complex formation (Fig. 9, trapping assay) and the time course of p 27 phosphorylation in the absence of histone $\mathrm{H} 1$ (Fig. 8A). All these results support a model involving slow progression of p 27 to the tightly bound state.

If ATP interferes with the ability of p27 to bind tightly and inhibit cyclin E-CDK2, then it should also affect the ability of $\mathrm{p} 27$ to inhibit histone $\mathrm{Hl}$ phosphorylation. Figure $10 \mathrm{C}$ shows a time course of histone $\mathrm{H} 1$ phosphorylation at a fixed concentration of $\mathrm{p} 27$ as a function of increasing ATP. At low ATP there is a burst of histone $\mathrm{H} 1$ phosphorylation followed by almost complete inhibition of further kinase activity. As predicted, increasing $A T P$ reduces cyclin $E-C D K 2$ inhibition, indicating that ATP retards conversion of p27 to the tightly bound, inhibited state (as in Fig. 8B). The percent inhibition decreased 7.5-fold as the ATP concentration increased from 50 to $1000 \mu \mathrm{M}$. In contrast, when p 27 and cyclin E-CDK2 were preincubated the percent inhibition was unchanged 
A

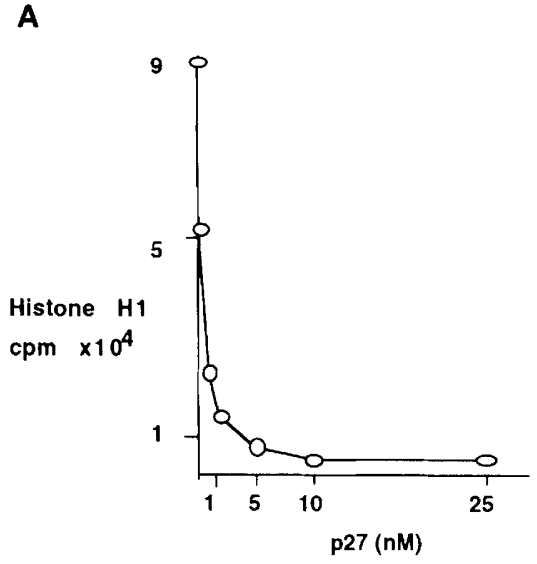

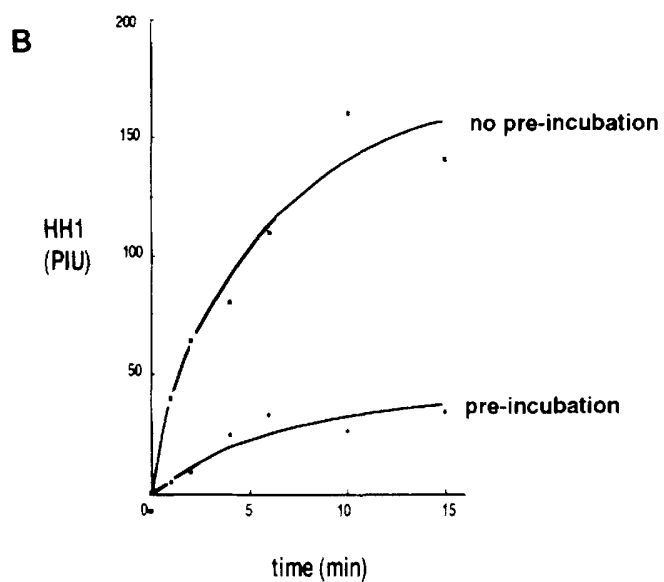

C

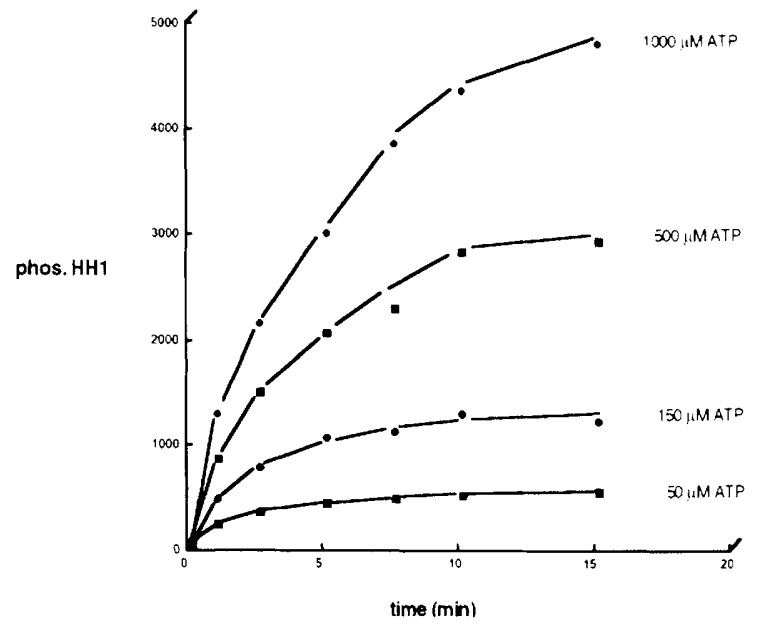

Figure 10. Kinetics of $\mathrm{p} 27$ inhibition of histone $\mathrm{Hl}$ phosphorylation. (A) Inhibition of histone $\mathrm{Hl}$ phosphorylation as a function of $\mathrm{p} 27$ concentration. The reaction contained 3 $\mu \mathrm{M}$ histone $\mathrm{H} 1$ and was initiated with cyclin E-CDK2, followed by quenching after $20 \mathrm{~min}$ at $37^{\circ} \mathrm{C}$. (B) Kinetics of inhibition at a fixed concentration of $\mathrm{p} 27(10 \mathrm{nM})$ when the reaction was initiated with enzyme (no preincubation) or when enzyme is preincubated with p 27 before initiating the reaction (preincubation). The time course of histone phosphorylation is linear in the absence of $\mathrm{p} 27$ (data not shown). (C) Increasing ATP competes with inhibition of cyclin E-CDK2 by $\mathrm{p} 27$. Phosphorylation of histone $\mathrm{H} 1$ ( $3 \mu \mathrm{M})$ over time as a function of ATP concentration with a fixed amount of p27 $(0.5 \mu \mathrm{M})$. The reaction was initiated with enzyme and carried out at $37^{\circ} \mathrm{C}$.

by high ATP (data not shown). We propose that at high concentrations of ATP the residual inhibition of histone phosphorylation does not reflect inhibition by tight binding, but rather substrate competition between p27 and histone H1 (R. Sheaff and J. Roberts, in prep.). As ATP concentrations approach the physiological range, the ability of p27 to bind tightly to cyclin E-CDK2 and inhibit its catalytic activity declines. Instead, p27 serves as an alternative substrate of the enzyme.

\section{Discussion}

p27 has been depicted simply as a tight binding, negative regulator of cyclin-CDK complexes. Surprisingly, our observations suggest that the opposite relationship also exists: Cyclin E-CDK2 regulates $\mathrm{p} 27^{\mathrm{Kip}}{ }^{1}$. In vivo, cyclin E-CDK2 kinase activity reverses the inhibitory effect that p27 has on cell cycle progression and initiates a pathway that leads to elimination of $\mathrm{p} 27$ from the cell. We show that cyclin E-CDK2 phosphorylates p27 predominantly on T187 in vitro, that cyclin E-CDK2-p27 complexes harvested from cells phosphorylate p27 on this same site, and that induction of cyclin $\mathrm{E}$ in vivo causes $\mathrm{p} 27$ to be phosphorylated on T187. We show further that down-regulation of $\mathrm{p} 27$ in vivo is prevented both by mutation of $\mathrm{T} 187$ in $\mathrm{p} 27$ and by mutations that decrease the catalytic activity of cyclin E-CDK2 complexes. Together, these data suggest that cyclin E-CDK2 is likely to regulate 27 directly via phosphorylation of T187. This appears to be a specific property of cyclin E-CDK2 as cyclin D1-CDK4 neither phosphorylates p27 efficiently nor induces p27 elimination when overexpressed in cells. In sum, we have identified p27 as a cyclin E-CDK2 substrate, demonstrated the biological consequences of p27 phosphorylation, and developed a kinetic model to explain how a CDK inhibitor can itself be effectively regulated by a CDK.

Our data should not be interpreted to imply that cyclin $\mathrm{E}-\mathrm{CDK} 2$ is the only regulator of p27 in vivo. Other enyzmes, such as cyclin A-CDK2, may also phosphorylate $\mathrm{p} 27$, and $\mathrm{p} 27$ levels may also be modulated by phosphorylation-independent mechanisms.

\section{Regulation of $\mathrm{p} 27$ by phosphorylation}

Our observations establish that cyclin E-CDK2 downregulates the ability of $\mathrm{p} 27$ to block cell cycle progression. One interpretation is that elimination of $\mathrm{p} 27$ is not directly caused by cyclin E-CDK2, but rather is an indirect consequence of entry into $S$ phase. In this model, phosphorylated $\mathrm{p} 27$ would be intrinsically less capable of arresting the cell cycle, perhaps because it becomes a less 
effective CDK inhibitor. Functional inactivation of p27 could promote progression through $G_{1}$, with the subsequent decline in $\mathrm{p} 27$ protein being a result of a pathway that is induced only after entry into $\mathrm{S}$ phase. This pathway would not necessarily depend upon $\mathrm{p} 27$ phosphorylation, and the elimination of $\mathrm{p} 27$ would be a consequence, not a cause of S-phase entry. Our data do not support this model. First, in vitro experiments show that wild-type and phosphorylation site mutants of p27 inhibit CDK2 equally well. Second, we show that p27 degradation is not simply a consequence of entry into $\mathrm{S}$ phase. Overexpression of cyclin D1-CDK4 overrides a p27-imposed $G_{1}$ block and promotes S-phase entry, but this is not accompanied by a decline in $\mathrm{p} 27$ protein levels. Instead, p27 is present in cyclin D1-CDK4 complexes. Finally, p27(T187A) can be expressed at high levels in S-phase cells, whereas wild-type p27 cannot B. Clurman, R. Sheaff, M. Groudine, and J. Roberts, unpubl.).

Our data strongly support the alternative explanation that phosphorylation of $\mathrm{p} 27$ leads directly to decreased p27 protein abundance, and that this provides the impetus for entry into $S$ phase. In this model, the pathway for p27 elimination may be constitutively active, but would recognize p27 only after it had been phosphorylated by cyclin E-CDK2. There are clear parallels between this model for the regulation of $\mathrm{p} 27$ in mammalian cells and the regulation of S-phase entry by the CKI p $40^{\text {Sicl }}$ in Saccharomyces cerevisiae (Mendenhall 1993; Schwob et al. 1994; Schneider et al. 1996). p27 can be degraded via the ubiquitin-proteosome pathway, and this may be regulated during the cell cycle (Pagano et al. 1995). Because ubiquitin-mediated proteolysis is commonly regulated by substrate phosphorylation, it is tempting to speculate that the increased phosphorylation of $\mathrm{p} 27$ by cyclin E-CDK2 promotes its degradation. Indeed, phosphorylation of cyclin $\mathrm{E}$ itself by cyclin E-CDK2 has been shown to promote its degradation by the ubiquitin-proteosome pathway (Clurman et al. 1996b; Won and Reed 1996). Translational control of p27 expression is also cell cycle-regulated, and decreased translational efficiency of p27 mRNA is an important determinant of reduced p27 expression in S phase (Hengst and Reed 1996). The possible relationship between $\mathrm{p} 27$ phosphorylation and p27 translation is less clear.

\section{Cell cycle control by cyclin $E$ and $p 27$}

The data suggest that $\mathrm{p} 27$ and cyclin E-CDK2 oppose each other's actions, with cell cycle progression hanging in the balance. Either CDK2 is inactive, p27 is abundant, and the cell cycle is stopped, or CDK2 is active, p27 is gone, and the cell cycle proceeds into $S$ phase. This binary (all or none) model embodies the general idea that a switch between two physiological states can be governed by two mutually inhibitory pathways. In the example studied here, the position of this switch will be very sensitive to small changes in the amount of active cyclin E-CDK2. Any stimulus that causes accumulation of active cyclin E-CDK2 should trigger a feedback loop in which cyclin E-CDK2 down-regulates p27 and activates more cyclin E-CDK2. Therefore, the switch from inactive to active CDK2 is binary, because this positive feedback loop would make any intermediate state intrinsically unstable.

How do we view the operation of this pathway during the cell cycle? In early $G_{1}$ or in quiescent cells p 27 protein levels are elevated, and if cyclin E-CDK2 is present its kinase activity is inactive. Small, accidental, or random (subthreshold) increases in cyclin E-CDK2 should not be sufficient to initiate this feedback loop, to insure that p27 elimination occurs only in response to a biologically relevant mitogenic signal. The simplest explanation would be for p27 itself to impose a barrier to CDK2 activity that could not be overcome until cyclin $\mathrm{E}$ levels were sufficiently high. Alternatively, CDK regulation could be accomplished by one of many possible p27-independent ways of buffering CDK2 activity (Hoffman et al. 1994; Bresnahan et al. 1996; S. Coats and J.M. Roberts, unpubl.). It is also likely that the pathways leading to the elimination of phosphorylated p27 are themselves subject to thresholds or other regulatory effects. In response to a mitogenic stimulus these constraints on cyclin E activation or p27 elimination would be surpassed. Activation of the p27 elimination loop would then allow for the transition from a state with low CDK2 activity to one with high $\mathrm{CDK} 2$ activity, thereby promoting the transition from $G_{1}$ to $S$ phase.

\section{Kinetic studies of the interaction of p27 with cyclin E-CDK2: p27 as a CDK2 inhibitor}

Kinetic analysis shows that the pathway through which p27 interacts with cyclin E-CDK2 passes through stages in which p 27 is first a substrate and then an inhibitor of the enzyme. The most important features of this kinetic model are that p27 initially engages cyclin E-CDK2 in a transient, loosely bound state. At this point the enzymep27 complex can slowly convert to a catalytically inactive form that is likely to closely resemble the crystal structure of p27-cyclin A-CDK2 solved recently (Russo et al. 1996). If instead CDK2 binds ATP, the enzyme becomes committed to $\mathrm{p} 27$ phosphorylation and release. Thus, the equilibrium between the loosely and tightly bound states can be modulated by the ambient ATP concentration (and possibly other extrinsic factors), thereby determining whether $\mathrm{p} 27$ is mainly a CDK inhibitor or a CDK substrate. The observation that increasing the ATP concentration increases $\mathrm{p} 27$ phosphorylation by favoring formation of the loose complex implies that ATP does not bind to the tight, catalytically inactive species. Otherwise, increasing the ATP concentration should not have favored one complex over the other. These conclusions are in complete agreement with the crystal structure of 27 bound to cyclin A-CDK2, which depicts a single p27 interacting with the ATP binding domain on CDK2 (Russo et al. 1996).

Kinetic studies of the interaction of p27 with cyclin E-CDK2: p27 as a CDK2 substrate

Histone $\mathrm{Hl}$ is the standard substrate utilized as a barom- 
eter of cyclin-CDK kinase activity. A central argument for classifying p27 as an inhibitor of cyclin-CDKs has been its ability to potently inhibit histone $\mathrm{Hl}$ phosphorylation. Nevertheless, the fact that p27 is phosphorylated by cyclin E-CDK2 indicates it is also a substrate of the enzyme. A priori there is no reason to assume that the kinetics of histone $\mathrm{Hl}$ phosphorylation reflect the physiological properties of the cyclin E-CDK2 enzyme. In fact, the ability of most cyclin-CDK complexes to phosphorylate histone $\mathrm{Hl}$ suggests just the opposite; histone $\mathrm{Hl}$ may be more like a peptide substrate because it may lack interactions with the cyclin subunit important for substrate selection in vivo. p27 is therefore more likely to be a true substrate in that it clearly interacts with the cyclin, using motifs present in other known cyclin-CDK substrates, such as the Rb family members (Zhu et al. 1995).

Deletion analysis has shown that only the amino terminus of p27 (amino acids 1-129) tightly binds the cyclin-CDK complex, and that it is sufficient for inhibition of histone $\mathrm{Hl}$ phosphorylation (Lou et al. 1995). Our data show that establishment of the tightly bound form is slow and that p27 is phosphorylated during its initial interaction with enzyme. We propose, therefore, that the initial reversible interaction of $\mathrm{p} 27$ with cyclin E-CDK2 minimally involves the carboxyl terminus of p27 containing the CDK2 phosphorylation site. In the absence of ATP this intermediate proceeds through a slow step to form the tightly bound, inhibited complex. Conversion to the tightly bound state likely involves the stabilizing influence of the p27 amino terminus on the cyclinCDK-p27 complex (as in the crystal structure), which is lacking or attenuated in the loose intermediate. Alternatively, interaction of the amino terminus of $\mathrm{p} 27$ with the enzyme could be required for $\mathrm{p} 27$ phosphorylation, as has been proposed for 107 and other cyclin-binding proteins (Zhu et al. 1995). This predicts that deletion of the cyclin-binding portion of p27 would make the carboxyl terminus a poor CDK substrate by impairing its ability to bind correctly to the enzyme. However, the opposite is true. Deletion of the amino terminus does not decrease p 27 phosphorylation (not shown). In fact, the carboxyl terminus becomes a much better substrate of the cyclin E-CDK2 enzyme, probably because it cannot convert to the tightly bound form.

The implication of our work is that there are conditions in which p27 may not be stably associated with cyclin E-CDK2 in cells. Is this consistent with previous data that have been interpreted to demonstrate p27 is a cyclin E-CDK2 inhibitor in cells (Polyak et al. 1994a; Toyoshima and Hunter 1994)? The $G_{1}$ arrest associated with $\mathrm{p} 27$ overexpression has been attributed to inhibition of multiple CDKs, including cyclin E-CDK2. However, overexpression of a CDK2 substrate could have the same effect simply by out-competing other substrates required for cell cycle progression. Likewise, cyclin E-CDK2 immunoprecipitated from extracts of nonproliferating cells is stoichiometrically associated with $\mathrm{p} 27$ (Nourse et al. 1994; Slingerland et al. 1994; Coats et al. 1996). Given the fact that the ATP concentration appears to alter the affinity of $\mathrm{p} 27$ for cyclin E-CDK2, the stoichiometric binding detected by this approach may arise only after cell lysis into buffers containing subphysiological amounts of ATP. Alternatively, in vivo there may be factors that modulate the ATP effect and promote stable binding of $\mathrm{p} 27$ to cyclin E-CDK2 and concomitant inhibition of catalytic activity.

The present work identifies an alternative outcome for the interaction between p27 and cyclin E-CDK2 in which p27 is a substrate rather than an inhibitor of the enzyme. Thus, elimination of $\mathrm{p} 27$ by cyclin E-CDK2 may define a pivotal transition in the cell cycle-from a state in which proliferation is inhibited by $\mathrm{p} 27$ to a state in which CDK2 drives cells into $\mathrm{S}$ phase.

\section{Materials and methods}

\section{Cell culture, plasmids, transfections, cell cycle analysis}

NIH-3T3 cells were obtained from C. Sherr (St. Judes Childrens' Research Hospital, Memphis, TN) and grown in Dulbecco's modified Eagle medium (DMEM) supplemented with $10 \%$ fetal bovine serum (Hyclone). For Western and immunoprecipitation analyses, cells were transfected in $60-$ or $100-\mathrm{mm}$ dishes 1375,000 or 750,000 cells, respectively) by the calcium phosphate method as follows: Plasmid DNAs were suspended in 0.25 $\mathrm{ml}$ of $122 \mathrm{mM} \mathrm{CaCl}_{2}$ and added dropwise to $0.25 \mathrm{ml}$ of $2 \times$ HEPES-buffered saline, mixed once, and immediately added dropwise to plates. For most analyses, total DNA concentrations per dish were fixed at $6 \mu \mathrm{g}$ per $60-\mathrm{mm}$ dish by adding empty vectors to transfections such that the amount of various expression vectors was normalized to control for promoter competition effects lother DNA concentrations used are noted belowl. Transfection efficiencies were monitored by the inclusion of cytomegalovinus (CMV)- $\beta$-galactosidase $1250 \mathrm{ng}$ per $60-\mathrm{mm}$ dish and the cell lysates were analyzed for $\beta$-gal activity by standard methods. For cell cycle analysis, $100-\mathrm{mm}$ dishes were seeded with $500,000 \mathrm{NIH}-3 \mathrm{~T} 3$ cells and transfected with $10 \mu \mathrm{g}$ of cyclin plasmid, $10 \mu \mathrm{g}$ CS2p27, $5 \mu \mathrm{g}$ CMVCD20 per plate; $3 \mu \mathrm{g}$ $\mathrm{cdk}$ plasmids were included as indicated. Forty-eight hours after transfection, cells were harvested with phosphate-buffered saline (PBS)-3 mM EDTA and stained with $\alpha$-CD20 antibody (Becton-Dickinson) and propidium iodide as described (van den Heuval and Harlow 19931. Cells were analyzed on a FACSCAN II followed by data analysis with MultiCycle.

The following plasmids were used for transfections: pCS2mcyclin E (Clurman et al. 1996b), pCMV-CDK2, pCMV-dnCDK2, pCMV-CDK4, and pCMVCD20 (S. van den Heuval and E. Harlow, Massachusetts General Hospital, Charlestown, MA); pCS2p27 (M. Ohtsubo, FHCRC), p15-1 neo [M. Gossen, Center for Molecular Biology-Heidelberg (ZMBH), Germany]. CS2p $27 \mid \mathrm{T} 187 \mathrm{~A}$ l was generated from CS2p27 by converting thr187 to an alanine residue by site-directed mutagenesis of single-stranded template DNA by standard methods (Kunkel et al. 1987). pCS2m-cyclin E(188-191A) was generated from pCS2 $\mathrm{m}$-cyclin $\mathrm{E}$ by site-directed mutagenesis by use of a primer that converted residues $188-191$ to alanines. p-tet-cyclin E was derived from ptet-p27 (I. Reynisdottir, Sloan-Kettering Institute, New York, NY) by removing the p27 insert with BamHI, Klenow treatment, and blunt-end ligation with the Klenowtreated $1.6 \mathrm{~kb}$ EcoRI fragment containing the myc-epitopetagged cyclin E cDNA derived from pCS2m-cyclin E. PCS2mcyclin D1 was prepared from a PCR-generated fragment of cyclin Dl contained within CS2D1 lobtained from B. Kelly, 
FHCRCl. The fragment was digested with $X$ hol and ligated into CS2MT that had been Xhol-digested.

\section{Antibodies}

$9 \mathrm{E} 10$ (anti-myc tag) was prepared by an in-house biologic production facility; $\alpha$-p27, and $\alpha$-cyclin $E$ have been described previously (Koff et al. 1992; Coats et al. 1996). $\alpha$-CDK2 (M2) was obtained from Santa Cruz. $\alpha$-CD20 was a gift from I. Bernstein (FHCRC) and fluorescein isothiocyanate (FITC)-conjugated by standard methods. $\alpha$-Hemagglutinin $(\alpha$-HA) (12CA5) was obtained from BAbCO. HRP-conjugated anti-mouse and anti-rabbit IgG antibodies were obtained from Amersham.

\section{Western blotting analysis and immunoprecipitation}

Cells were lysed directly on $60-\mathrm{mm}$ tissue culture dishes in 0.4 $\mathrm{ml}$ RIPA buffer $\{10 \mathrm{~mm}$ Tris at $\mathrm{pH} 7.4,0.15 \mathrm{M} \mathrm{NaCl}, 1 \% \mathrm{NP}-40$, $1 \%$ deoxycholate, $0.1 \%$ SDS) containing protease and phosphatase inhibitors $(10 \mu \mathrm{g} / \mathrm{ml}$ each of aprotonin, leupeptin, and pepstatin, $50 \mathrm{~mm} \mathrm{NaF}, 1 \mathrm{~mm} \mathrm{Na}$ vanadate), followed by scraping and sonication. Protein concentrations were determined by Bradford assays, and $15 \mu \mathrm{g}$ of cell extracts were electrophoresed on $12 \%$ polyacrylamide gels. After transferring to PVDF membranes as described previously (Koff et al. 1992; Clurman et al. 1996 b), proteins were detected by incubation with appropriate primary antibodies followed by HRP-conjugated anti-rabbit or anti-mouse IgG secondary antibodies and ECL detection performed as described by the manufacturer (Amersham).

Immunoprecipitation of lysates from transfected cells was performed as follows: Approximately $200 \mu \mathrm{l}$ of cell lysates were normalized for protein concentration and incubated at $4^{\circ} \mathrm{C}$ for $30 \mathrm{~min}$ with appropriate dilutions of the indicated antibodies, followed by the addition of $30 \mu$ of a $1: 1$ slurry of protein A-Sepharose (Sigma) or Gammabind-plus Sepharose (Amersham) suspended in RIPA buffer. After rotating $30 \mathrm{~min}$ at $4^{\circ} \mathrm{C}$, the beads were pelleted and washed four times with RIPA buffer, then quenched in SDS loading buffer and separated by SDS-polyacrylamide gel electrophoresis (PAGE) followed by Western transfer where indicated. Histone $\mathrm{Hl}$ kinase assays were performed as described previously (Koff et al. 1992).

\section{Phosphopeptide and phosphoamino acid analyses}

Phosphopeptide and phosphoamino acid analysis were performed essentially as described by Boyle et al. (1991). P27 protein that had been phosphorylated in vitro or in vivo (see below), was electrophoresed on $12 \%$ denaturing acrylamide gels and the bands visualized by autoradiography. Gel pieces containing the band of interest were eluted by homogenization in $50 \mathrm{~mm}$ ammonium bicarbonate, incubation at $4^{\circ} \mathrm{C}$ overnight, and TCA precipitation after the addition of $5 \mu \mathrm{g}$ of ribonuclease $\mathrm{A}$ as carrier protein. The precipitates were extracted with $50 \%$ ethanol-50\% ether, dried, and oxidized by treatment with $20 \mu \mathrm{l}$ of performic acid (prepared by adding $0.01 \mathrm{ml}$ of $30 \mathrm{vol} / \mathrm{strength}$ hydrogen peroxide to $100 \mu \mathrm{l}$ of formic acid) on ice for $1 \mathrm{hr}$. Following lyopholization with $0.4 \mathrm{ml}$ of water, the pellets were treated with $10 \mu \mathrm{g}$ of TPCK-trypsin for at least $8 \mathrm{hr}$ at $37^{\circ} \mathrm{C}$. The pellets were then lyopholized three times in $0.4 \mathrm{ml}$ of water, and resuspended in 5-10 $\mathrm{\mu l}$ of $\mathrm{pH} 1.9$ buffer $(50 \mathrm{ml}$ of formic acid/ $156 \mathrm{ml}$ of glacial acetic acid per $7794 \mathrm{ml}$ water) prior to spotting on thin layer chromatography (TLC) plates.

Phosphopeptides were spotted on cellulose-TLC plates and electrophoresed at $1200 \mathrm{~V}$ for $25 \mathrm{~min}$ in a noncommercial apparatus (provided by J. Cooper, FHCRC). After drying, TLC was performed by placing the plates in a chromatography tank con- taining isobutyric acid buffer $(1250 \mathrm{ml}$ of isobutyric acid, $38 \mathrm{ml}$ of $n$-butanol, $96 \mathrm{ml}$ of pyridine, $58 \mathrm{ml}$ of glacial acetic acid, 558 $\mathrm{ml}$ of water) for $8 \mathrm{hr}$. Plates were air-dried, and then exposed by either autoradiography or PhosphorImager analysis.

For phosphoamino acid analyses of undigested p27, pellets prepared as above were resuspended in $50 \mu \mathrm{l}$ of $5.7 \mathrm{M} \mathrm{HCl}$ following the ethanol-ether extraction, and incubated at $110^{\circ} \mathrm{C}$ for 1-2 hr. Following lyophilization, the pellets were resuspended in $3 \mu \mathrm{l}$ of $\mathrm{pH} 1.9$ buffer containing $0.1 \mu \mathrm{g} / \mathrm{ml}$ of cold phosphoamino acids. For phosphoamino acid analyses of peptides, the peptides were recovered from TLC plates following autoradiography or PhosphorImager analysis by scraping and elution in $\mathrm{pH} 1.9$ buffer, and treated as above. Phosphoamino acids were spotted as above and electrophoresed at $1600 \mathrm{~V}$ for $16 \mathrm{~min}$ in $\mathrm{pH}$ 1.9 buffer. After drying, the plates were rotated $90^{\circ}$ and electrophoresed in $\mathrm{pH} 3.5$ buffer $(100 \mathrm{ml}$ of glacial acetic acid, $10 \mathrm{ml}$ of pyridine, $1890 \mathrm{ml}$ of water) at $1600 \mathrm{~V}$ for $16 \mathrm{~min}$. The position of the cold amino acids was visualized by spraying with $0.1 \%$ ninhydrin, and the plates were exposed by either PhosphorImager analysis or autoradiography.

\section{In vivo analysis of p27 phosphorylation}

Hundred-millimeter dishes were seeded with 750,000 cells and transfected as above with $10 \mu \mathrm{g}$ of p-tet-E, $1.2 \mu \mathrm{g}$ of CS2 p27 or CS2 p27(T187A), $3 \mu \mathrm{g}$ of CMV-CDK2, and $1 \mu \mathrm{g}$ of p15-lneo (encoding the tetracycline transactivator protein). Tetracycline $(1 \mu \mathrm{g} / \mathrm{ml})$ was added to the growth media at the time of transfection and maintained until noted below. The transfection media was changed after $12 \mathrm{hr}$, and after an additional $24 \mathrm{hr}$ plates were washed six times with Tris-buffered saline and the media replaced with or without tetracycline. After $4 \mathrm{hr}$ the media was replaced with $2 \mathrm{ml}$ of phosphate-free DMEM (ICN) with or without tetracycline containing $1 \mathrm{mCi} / \mathrm{ml}\left[{ }^{32} \mathrm{P}\right]$ orthophospate (ICN, $10 \mathrm{mCi} / \mathrm{ml}$ ). After $4 \mathrm{hr}$ of labeling the cells were lysed with $1 \mathrm{ml}$ of RIPA/plate /containing $50 \mathrm{~nm}$ okadeic acid and 10 $\mathrm{mm} \beta$-glycerol phosphate in addition to the protease and phosphatase inhibitors indicated above) and passed through a $26 \mathrm{G}$ needle several times to reduce viscosity. Cell lysates were precleared with normal rabbit serum and protein $\mathrm{A}-\mathrm{Sepharose}$, and immunopreciptated with $10 \mu \mathrm{l}$ of $\alpha$-p27 antibody/ml of lysate as above.

\section{In vivo immunoprecipitation kinase assay}

NIH-3T3 cells seeded on 100-mM dishes were transfected with $10 \mu \mathrm{g}$ of myc epitope-tagged cyclin, $3 \mu \mathrm{g}$ of cdk, and $3.6 \mu \mathrm{g}$ of $\mathrm{p} 27$ plasmids as indicated. Two plates of each mix were lysed and combined in Tween 20 lysis buffer $\{50$ mM HEPES at pH 7.5, 150 $\mathrm{mm} \mathrm{NaCl}, 2.5 \mathrm{~mm}$ EGTA, $1 \mathrm{~mm}$ EDTA, $0.1 \%$ Tween 20 , protease/phosphatase inhibitors as above). Lysates were frozen on dry ice, than thawed and incubated on ice for $1 \mathrm{hr}$ and the supernatants cleared by centrifugation. Lysates were immunoprecipitated with $1 / 10$ volume $9 E 10$ and washed three times in Tween lysis buffer and twice in kinase buffer $150 \mathrm{~mm}$ HEPES at $\mathrm{pH} 7.5,10 \mathrm{mM} \mathrm{MgCl}_{2}$ ). After the last wash the immunoprecitates were resuspended in $20 \mu \mathrm{l}$ of kinase buffer containing $1 \mu \mathrm{M}$ cold ATP plus $0.5 \mu$ l of $\left[\gamma^{-32} \mathrm{P}\right] \mathrm{ATP}(6000 \mathrm{Ci} / \mathrm{mmole}, \mathrm{NEN})$ and incubated at $30^{\circ} \mathrm{C}$ for $30 \mathrm{~min}$.

\section{Protein purification}

Sf9 insect cells were coinfected with histidine-tagged human cyclin E and HA-tagged human CDK2 baculoviruses (gift of David Morgan, University of California, San Franciscol to generate the cyclin E-CDK2 complex. This complex was then purified by $\mathrm{Ni}^{2+}$ column chromotography by use of the six-histi- 
dine tag of the cyclin $\mathrm{E}$ gene as directed by the manufacturer (Novagen). Purified enzyme was stored in $20 \mathrm{~mm}$ HEPES, $10 \mathrm{~mm}$ $\mathrm{NaCl}, 1 \mathrm{~mm}$ DTT, and $50 \%$ glycerol at $-20^{\circ} \mathrm{C}$. For the trapping assays, cyclin E-CDK2 complexes were purified as $40 \mathrm{~K}$ spin lysates. EcoRI fragments encoding the human p27 and $\mathrm{p} 27$ (T187A) proteins were cloned into pet $16 \mathrm{~B}$ vectors (Novagen) and purified from Escherichia coli using a 6-amino-acid carboxy-terminal histidine tag according to the manufacturer's di-

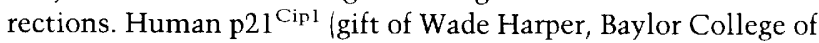
Medicine, Houston, TX| was purified from the insoluble fraction of an $E$. coli lysate by solubilizing in urea followed by $\mathrm{Ni}^{2+}$ column chromatography. The urea was removed by dialysis and the protein stored in $50 \mathrm{~mm}$ Tris at $\mathrm{pH} 8,100 \mathrm{~mm} \mathrm{NaCl}, 2 \mathrm{~mm}$ DTT, and $10 \%$ glycerol. Protein concentrations were determined by Bradford assay as compared with a BSA standard.

\section{Enzyme concentration}

The concentration of purified cyclin E-CDK2 was determined by silver staining polyacrylamide gels and comparing the amounts of cyclin and CDK2 to known concentrations of these proteins purified from $E$. coli. By this measure the enzyme concentration was $\sim 70 \mathrm{~nm}$. We also measured the amount of active enzyme in the preparation. Because cyclin E-CDK2 complex autophosphorylates cyclin $\mathrm{E}$ in the presence of ATP, the amount of active cyclin E-CDK2 complex could be estimated by determining the amount of cyclin E phosphorylated when $\left[{ }^{32} \mathrm{P}\right] \mathrm{ATP}$ was added to a fixed amount of cyclin E-CDK2. This technique gave a value of $32 \mathrm{~nm}$. To rule out the possibility that the majority of the cyclin E was already phosphorylated, we repeated the experiment with an excess of p27 in the reaction. At low ATP concentrations the amount of p27 phosphorylated was similar to the amount of phosphorylated cyclin $E$ in the absence of p27 (e.g., see Fig. 3A). Because under these conditions p27 likely binds in a 1:1 stoichiometry (Russo et al. 1996), this result suggests the amount of phosphorylated cyclin $\mathrm{E}$ is a reasonable reflection of the active cyclin $\mathrm{E}-\mathrm{CDK} 2$ in the reaction.

\section{In vitro kinase assays}

Phosphorylation of histone $\mathrm{Hl}$ (Boehringer Mannheim) was carried out in 10- $\mu$ l reactions containing $50 \mathrm{~mm}$ Tris at $\mathrm{pH} 7.5,10$ $\mathrm{mM} \mathrm{MgCl} 2,1 \mathrm{~mm}$ DTT, $3 \mu \mathrm{M}$ histone $\mathrm{H1}$, the indicated concentrations of unlabeled ATP, $2 \mu \mathrm{Ci}\left[\gamma^{32} \mathrm{P}\right] \mathrm{ATP}$, and $\sim 0.6 \mathrm{nM}$ cyclin E-CDK2. Reactions were performed for the indicated times at $37^{\circ} \mathrm{C}$ and quenched by the addition of SDS gel loading buffer. Samples were separated by SDS-PAGE and the labeled histone $\mathrm{H} 1$ quantitated by PhosphorImager analysis. Phosphorylation of p27 $(2 \mu \mathrm{M})$ was analyzed in the same manner, except the amount of $\left[{ }^{32} \mathrm{P} \mid \mathrm{ATP}\right.$ was increased to $10 \mu \mathrm{Ci}$ per reaction and the amount of enzyme to $\sim 1-3 \mathrm{nM}$ to facilitate detection of labeled p27. Reactions were initiated as described in the figure legends.

\section{Trapping assays}

For determining stability of the cyclin E-CDK2-p27 complex, $20 \mathrm{nM} \mathrm{p} 27$ and $5 \mu \mathrm{l}$ of $40 \mathrm{k}$ spin cyclin E-CDK2 were allowed to reach equilibrium by preincubating for $10 \mathrm{~min}$ at $37^{\circ} \mathrm{C}$ in $50 \mathrm{~mm}$ Tris at $\mathrm{pH} 7.5,10 \mathrm{~mm} \mathrm{MgCl}, 2 \mathrm{~mm}$ DTT, and $1 \mathrm{mg} / \mathrm{ml}$ of BSA. Immunoprecipitation in the absence of $\mathrm{p} 21$ gave the maximal amount of $\mathrm{p} 27$ bound. hp2 $1^{\mathrm{Cip} 1}(800 \mathrm{nM})$ was added to the reaction for the indicated times at $37^{\circ} \mathrm{C}$, after which cyclin $\mathrm{E}$ was immunoprecipitated and the amount of associated p27 determined by Western analysis. The assembly rate was determined as above except the time of cyclin E-CDK2 and p27 preincubation was varied for the indicated times. $\mathrm{hp} 21^{\mathrm{Cip} 1}(800 \mathrm{nM})$ was then immediately added to prevent further $\mathrm{p} 27$ binding. This mixture was diluted into $250 \mu \mathrm{l}$ of RIPA buffer and the amount of associated $\mathrm{p} 27$ determined by immunoprecipitating cyclin $\mathrm{E}$.

\section{Acknowledgments}

We thank Jon Cooper for expert advice and assistance in phosphopeptide and phosphoamino acid analysis and Andrew Berger for assistance with FACSCAN analysis. This work was supported by National Institutes of Health grants CA64216 to B.E.C, CA54337 to M.G., and to J.R. B.E.C. is supported by the Jose Carerras Leukemia Foundation and R.J.S. is supported by the Cancer Research Fund of the Damon Runyon-Walter Winchell Foundation fellowship DRG-1313.

The publication costs of this article were defrayed in part by payment of page charges. This article must therefore be hereby marked "advertisement" in accordance with 18 USC section 1734 solely to indicate this fact.

\section{References}

Agrawal, D., P. Hauser, F. McPhersen, F. Dong, A. Garcia, and W.J. Pledger. 1996. Repression of p27kipl synthesis by platelet-derived growth factor in BALB/c 3T3 cells. Mol. Cell. Biol. 16: 4327-4336.

Boyle, W.J., P. Van Der Geer, and T. Hunter. 1991. Phosphopeptide mapping and phosphoamino acid analysis by two-dimensional separation on thin-layer chromotography plates. Methods Enzymol. 201: 110-148.

Bresnahan, W.A., I. Boldogh, T. Ma, T. Albrecht, and E.A. Thompson. 1996. Cyclin E/CDK2 activity is controlled by different mechanisms in the G0 and Gl phases of the cell cycle. Cell Growth Differ. 7: 1283-1290.

Clurman, B.E., J.M. Roberts, and M. Groudine. 1996a. Deregulation of cell cycle control in hematologic malignancies. Curr. Opin. Hematol. 3: 315-320.

Clurman, B.E., R. Sheaff, K. Thress, M. Groudine, and J. Roberts. 1996b. Turnover of cyclin $\mathrm{E}$ by the ubiquitin-proteasome pathway is regulated by CDK2 binding and cyclin phosphorylation. Genes \& Dev. 10: 1979-1990.

Coats, S., W.M. Flannagan, J. Nourse, and J. Roberts. 1996. Requirement of p27Kip1 for restriction point control of the fibroblast cell cycle. Science 272: 877-880.

Deng, C., P. Zhang, J. Harper, S. Elledge, and P. Leder. 1995. Mice lacking p21 CIP1/WAF1 undergo normal development, but are defective in G1 checkpoint control. Cell 82: 675-684.

Dulic, V., W. Kaufman, S. Wilson, T. Tlsty, E. Lees, J.W. Harper, S. Elledge, and S. Reed. 1994. p53-dependent inhibition of cyclin-dependent kinase activities in human fibroblasts during radiation-induced G1 arrest. Cell 76: 1013-1023.

El-Deiry, W.S., T. Tokino, V.E. Velculescu, D.B. Levy, R. Parsons, J.M. Trent, D. Lin, W.E. Mercer, K.W. Kinzler, and B. Vogelstein. 1993. WAFl, a potential mediator of p53 tumor suppression. Cell 75: 817-825.

Fang, G., N. Orend, T. Watanabe, T. Hunter and E. Ruoslahti. 1996. Dependence of cyclin E-CDK2 kinase activity on cell anchorage. Science 271: 499-502.

Fero, M.L., M. Rivkin, M. Tasch, P. Porter, C.E. Carow, E. Firpo, K. Polyak, L. Tsai, V. Broudy, R.M. Perlmutter, K. Kaushansky, and J.M. Roberts. 1996. A syndrome of multi-organ hyperplasia with features of gigantism, tumorigenesis and female sterility in p27 kipl-deficient mice. Cell 85: 733-744.

Firpo, E.J., A. Koff, M. Solomon, and J. Roberts. 1994. Inactivation of a CDK2 inhibitor during Interleukin 2-induced proliferation of human T lymphocytes. Mol. Cell. Biol. 14: 4889-4901.

Fersht, A. 1984. Enzyme structure and mechanism. W.H. Freeman, New York, NY. 
$\mathrm{Gu}, \mathrm{Y} ., \mathrm{C}$. Turek, and D. Morgan. 1993. Inhibition of CDK2 activity in vivo by an associated $20 \mathrm{~K}$ regulatory subunit. Nature 366: 707-710.

Harper, J.W, G.R. Adami, N. Wei, K. Keyomarsi, and S.J. Elledge. 1993. The $\mathrm{p} 21 \mathrm{CDK}$-interacting protein Cipl is a potent inhibitor of G1 cyclin-dependent kinases. Cell 75: 805-816.

Hauschka, P.V. 1973. Analysis of nucleotide pools in animal cells. Methods Cell. Biol. 7: 361-462.

Hengst, L. and S.I. Reed. 1996. Translational control of p27Kip1 accumulation during the cell cycle. Science 271: 1861-1864.

Hirai, H., M.F. Roussel, J.Y. Kato, R.A. Ashmun, and C.J. Sherr. 1995. Novel INK4 proteins, p19 and p18, are specific inhibitors of the cyclin D-dependent kinases CDK4 and CDK6. Mol. Cell. Biol. 15: 2672-2681.

Hoffmann, I., G. Draetta, and E. Karsenti. 1994. Activation of the phosphatase activity of human cdc25A by a CDK2-cyclin $E$ dependent phosphorylation at the G1/S transition. EMBO J. 13: 4302-4310.

Kamb, A. 1994. Role of a cell cycle regulator in hereditary and sporadic cancer. Cold Spring Harbor Symp. Quant. Biol. 49: $39-47$.

Kato, J.M., M. Matsuoka, K. Polyak, J. Massague, and C.J. Sherr. 1994. Cyclic AMP-induced G1 phase arrest mediated by an inhibitor (p27Kipl) of cyclin-dependent kinase-4 activation. Cell 79: 487-496.

Kiyokawa, H., R.D. Kineman, K.O. Manova-Todorova, V.C. Soares, M. Ono, D. Khanam, A.C. Hayday, L.A. Frohman, and A. Koff. 1996. Enhanced growth of mice lacing the cyclin-dependent kinase inhibitor p27kip1. Cell 85: 721-732.

Koff, A., D. Giordano, K. Desai, W. Yamashita, W. Harper, S. Elledge, T. Nishimoto, D. Morgon, R. Franza, and J. Roberts. 1992. Formation and activation of a cyclin E-CDK2 complex during the Gl phase of the human cell cycle. Science 257: 1689-1693.

Koff, A., M. Ohtsuki, K. Polyack, J. Roberts, and J. Massague. 1993. Negative regulation of G1 in mammalian cells: Inhibition of cyclin E-dependent kinase by TGF-beta. Science 260: 536-539.

Kunkel, T.A., J. Roberts, and R. Zakour. 1987. Rapid and efficient site-specific mutagenesis without phenotypic selection. Methods Enzymol. 154: 367-382.

Lou, Y., J. Hurwitz, and J. Massague. 1995. Cell-cycle inhibition by independent CDK and PCNA binding domains in $\mathrm{p} 21^{\mathrm{Cipl}}$. Nature 375: 159-161.

Mendenhall, M. 1993. An inhibitor of p34 CDC28 protein kinase activity from Saccharomyces cerevisiae. Science 259: $216-219$.

Morgan, D. 1995. Principles of CDK regulation. Nature 374: 131-144.

Nakayama, K., M. Ishida, M. Shirane, A. Inomata, T. Inoue, N. Shishido, I. Horii, D.Y. Loh, and K.-I. Nakayama. 1996. Mice lacking $27^{\mathrm{kip} 1}$ display increased body size, multiple organ hyperplasia, retinal dysplasia, and pituatary tumors. Cell 85: $707-720$.

Nobori, T., K. Miura, D.J. Wu, A. Lois, K. Takabayashi, and D.A. Carson. 1994. Deletions of the cyclin-dependent kinase-4 inhibitor gene in multiple human cancers. Nature 368: 753 756.

Noda, A., Y. Ning, S. Venable, O. Pereira-Smith, and J. Smith. 1994. Cloning of senescent cell-derived inhibitors of DNA synthesis using an expression screen. Exp. Cell Res. 211: 90-98.

Nourse, J., E. Firpo, M. Flanagan, M. Meyerson, K. Polyak, M.H. Lee, J. Massague, G. Crabtree, and J. Roberts. 1994. IL-2 mediated elimination of the $\mathrm{p} 27^{\mathrm{kip} 1}$ cyclin-CDK kinase inhibitor prevented by rapamycin. Nature 372: 570-573.

Pagano, M., S.W. Tam, A. Theodoras, P. Beer-Romero, G. Del
Sal, V. Chau, R. Yew, G. Draetta, and M. Rolfe. 1995. Role of the ubiquitin proteosome pathway in regulating abundance of the cyclin-dependent kinase inhibitor p27. Science 269: 682-685.

Polyak, K., M.H. Lee, H. Erdjument-Bromage, A. Koff, J.M. Roberts, P. Tempst, and J. Massague. 1994a. Cloning of p27 kipl: A cyclin-dependent kinase inhibitor and a potential mediator of extracellular antimitogenic signals. Cell 78: 59-66.

Polyak, K., J. Kato, M. Solomon, C. Sherr, J. Massague, J. Rob-

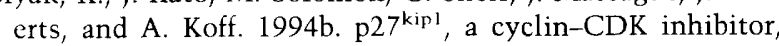
links transforming growth factor $\beta$ and contact inhibition to cell cycle arrest. Genes \& Dev. 8: 9-22.

Quelle, D.E., R.A. Ashmun, G.J. Hannon, P.A. Rehberger, D. Trono, K.H. Richter, C. Walker, D. Beach, C.J. Sherr, and M. Serrano. 1995. Cloning and characterization of murine p16INK4a and p15INK4b genes. Oncogene 11: 635-645.

Roberts, J.M., A. Koff, K. Polyak, E. Firpo, S. Collins, M. Ohtsubo, and J. Massague. 1994. Cyclins, CDKs, and cyclin kinase inhibitors. Cold Spring Harbor Symp. Quant. Biol. 59: 31-38.

Russo, A.A., P.D. Jeffrey, A.K. Patten, J. Massague, and N.P Pavletich. 1996. Crystal structure of the p27Kipl cyclin-dependent-kinase inhibitor bound to the cyclin A-CDK2 complex. Nature 382: 325-331.

Schneider, B., Y. Yang, and B. Futcher. 1996. Linkage of replication to start by the CDK inhibitor sicl. Science 272: 560-562.

Schwob, E., T. Bohm, M. Mendenhall, and K. Nasmyth. 1994. The B-type cyclins kinase inhibitor p40sicl controls the G1 to $S$ phase transition in S. cerevisiae. Cell 79: 233-244.

Serrano, M., G. Hannon, and D. Beach. 1993. A new regulatory motif in cell cycle control causing specific inhibition of cyclin D/CDK4. Nature 366:704-707.

Serrano, M., H. Lee, L. Chin, C. Cordon-Cardo, D. Beach, and R.A. DePinho. 1996. Role of the INK4a locus in tumor suppression and cell mortality. Cell 85: 27-37.

Sherr, C. 1994. G1 phase progression: Cycling on cue. Cell 79: 551-555.

Sherr, C. and J. Roberts. 1995. Inhibitors of mammalian $\mathrm{G}_{1}$ cyclin-dependent kinases. Genes \& Dev. 9: 1149-1153.

Slingerland, J., L. Hengst, C. Pan, D. Alexander, M.R. Stampfer, and S.I. Reed. 1994. A novel inhibitor of cyclin-CDK activity detected in transforming growth factor beta-arrested epithelial cells. Mol. Cell. Biol. 14: 3683-3694.

Toyoshima, H. and T. Hunter. 1994. p27, a novel inhibitor of G1-cyclin-CDK protein kinase activity, is related to p21. Cell 78: 67-74.

van den Heuval, S. and E. Harlow. 1993. Distinct roles for cyclin-dependent kinases in cell cycle control. Science 262: 2050-2054.

Won, K. and S. Reed. 1996. Activation of cyclin E/CDK2 is coupled to site-specific autophosphorylation and ubiquitindependent degradation of cyclin E. EMBO /. 15: 4182-4193.

Xiong, Y., G. Hannon, H. Zhang, D. Casso, R. Kobayashi, and D. Beach. 1993a. p21 is a universal inhibitor of cyclin kinases. Nature 366: 701-704.

Xiong, Y., H. Zhang, and D. Beach. 1993b. Subunit rearrangement of the cyclin-dependent kinases is associated with cellular transformation. Genes \& Dev. 7: 1572-1583.

Zhu, L., E. Harlow, and B.D. Dynlacht. 1995. p107 uses a p21 ${ }^{\mathrm{CIP} 1}$-related domain to bind cyclin/CDK2 and regulate interactions with E2F. Genes \& Dev. 9: 1740-1752.

Zhu, X., M. Ohtsubo, R.M. Bohmer, J.M. Roberts, and R. Assoian. 1996. Adhesion-dependent cell cycle progression linked to the expression of cyclin Dl, activation of cyclin E-CDK2 and phosphorylation of the retinoblastoma protein. I. Cell Biol. 133: 391-403. 


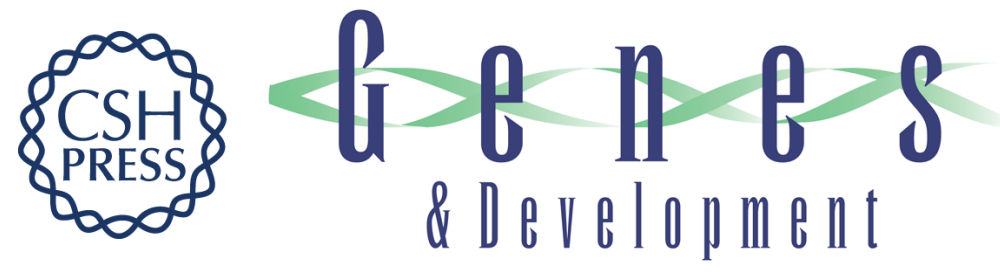

\section{Cyclin E-CDK2 is a regulator of p27Kip1.}

R J Sheaff, M Groudine, M Gordon, et al.

Genes Dev. 1997, 11:

Access the most recent version at doi:10.1101/gad.11.11.1464

References This article cites 51 articles, 21 of which can be accessed free at: http://genesdev.cshlp.org/content/11/11/1464.full.html\#ref-list-1

License

Email Alerting Service

Receive free email alerts when new articles cite this article - sign up in the box at the top right corner of the article or click here.

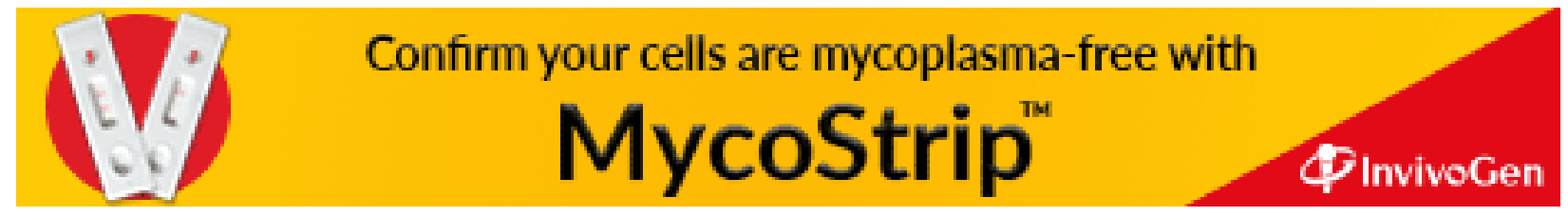

